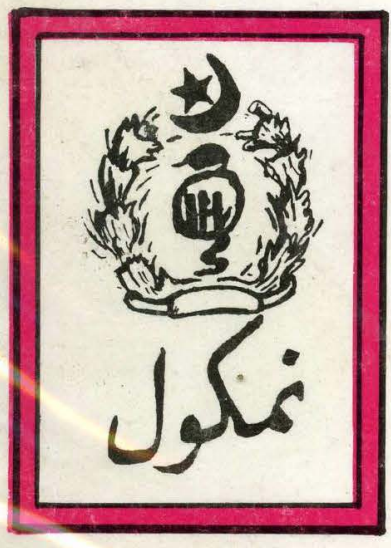

$$
\text { دناستى حخنيوى|وتلوى }
$$

Prevention and Treatment of Diarrhea

$$
\text { و6ه }
$$

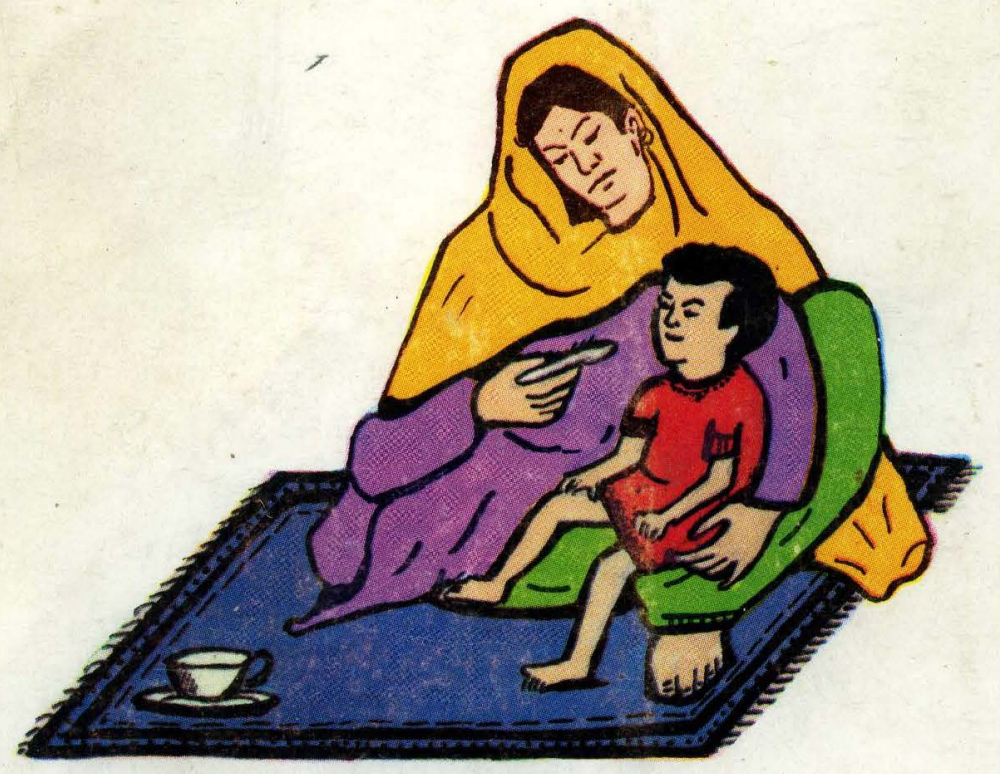



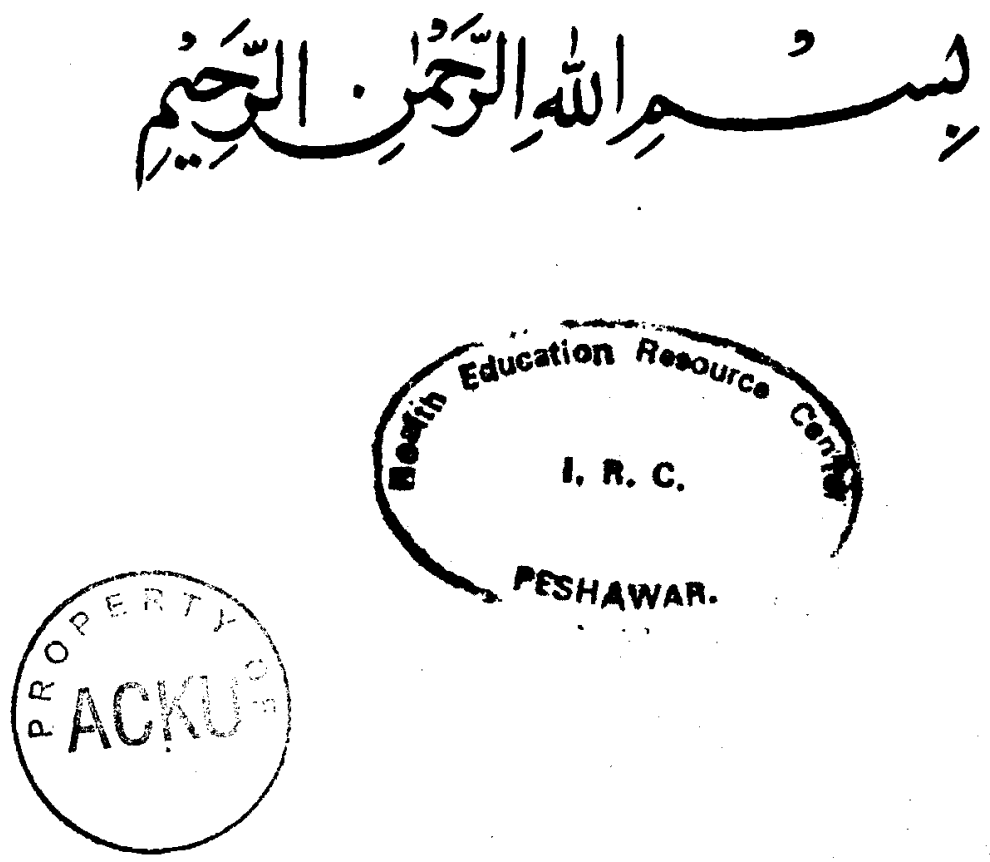
دناستىحنتوى اوتلاوى

\section{Prevention and Treatment of Diarrhea}

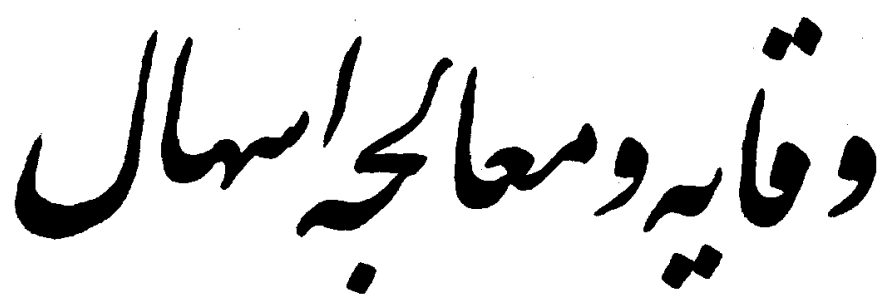




\section{دناستى حنتوى اوثناوى}

Prevention and Treatment of Diarrhea

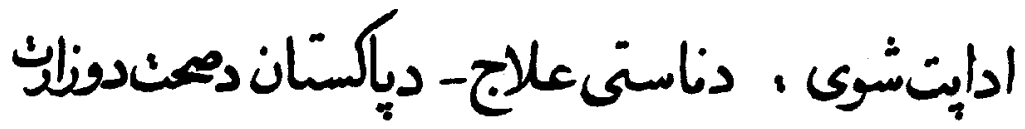

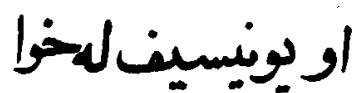

Adapted from: Treatment of Diarrhea by Ministry of Health of Pakistan \& UNICEF

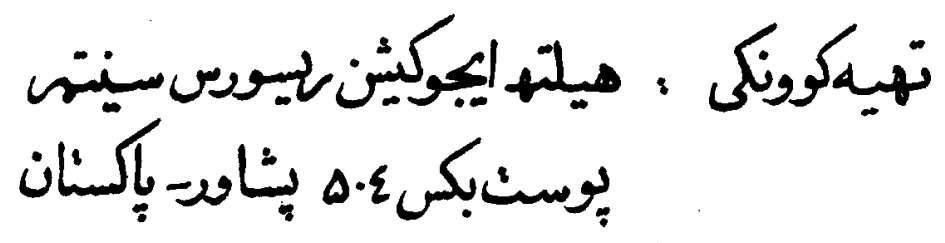

Produced by: Health Education Resource Center.

G. P. O. BOX 504,

Peshawar, Pakistan

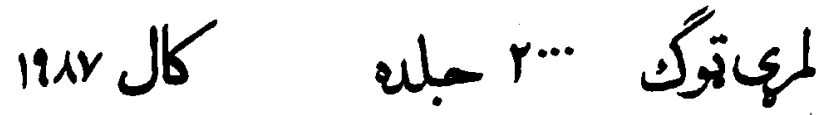

Year: 1987 First edition: 2000 copies 
و6.

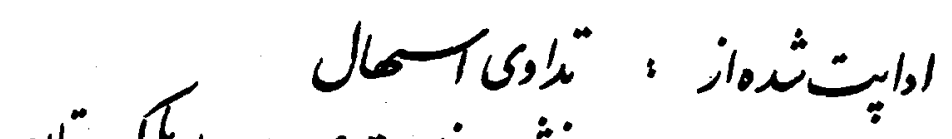

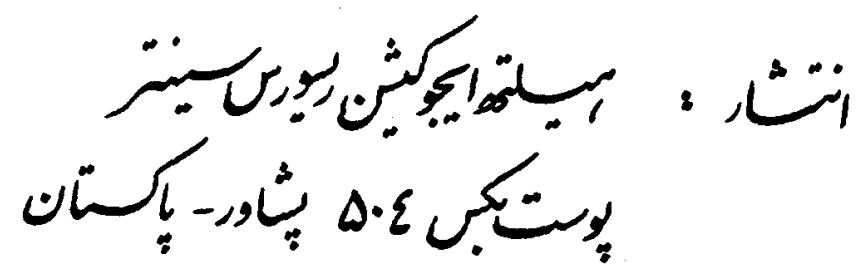

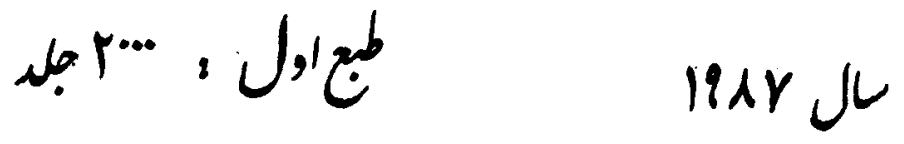


دديكاكتاب املى مدف دمبندو اوماسومانود بإِ ديوعملىمأغنذ

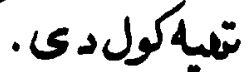

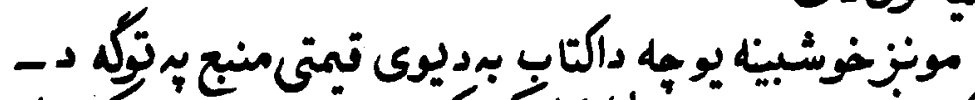

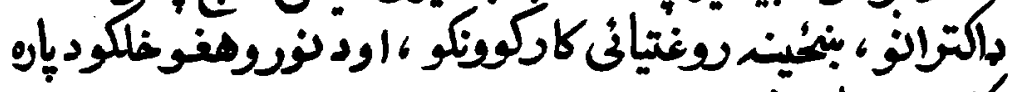

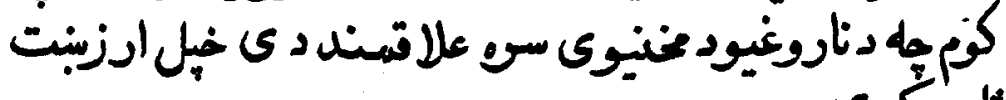

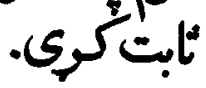

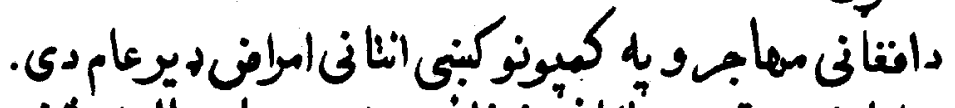

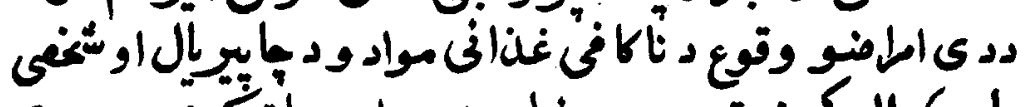

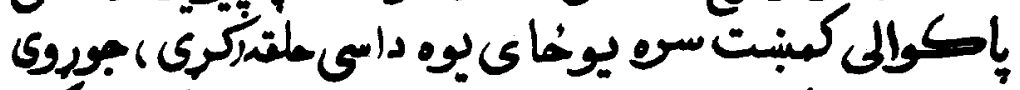

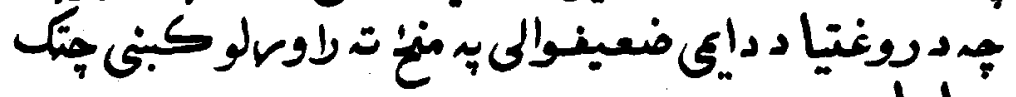

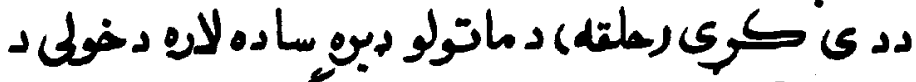

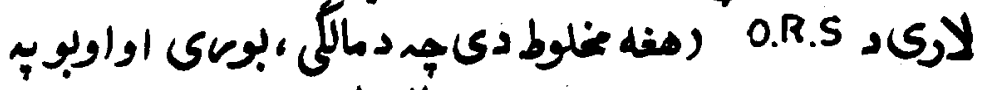

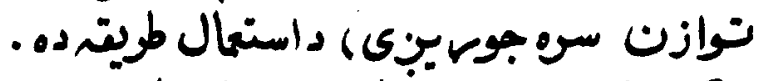

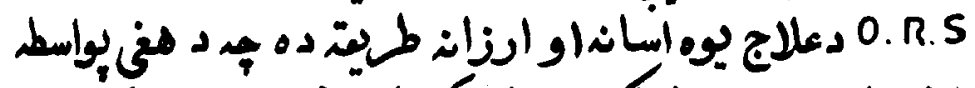

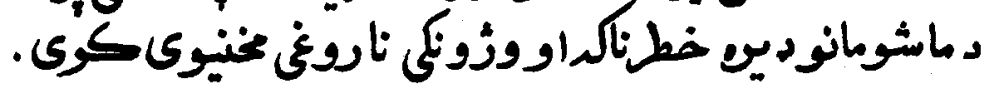




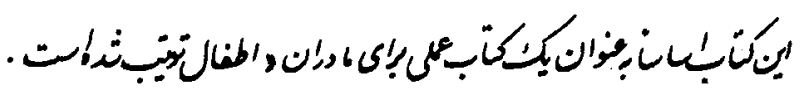

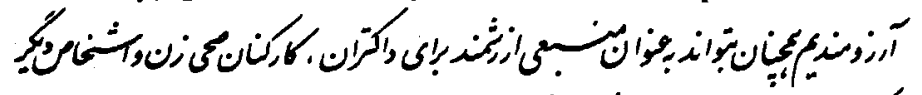

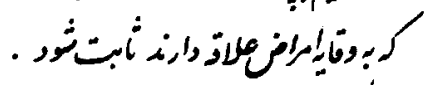

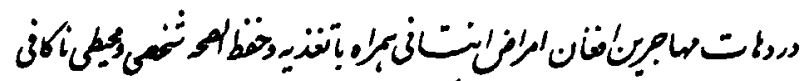

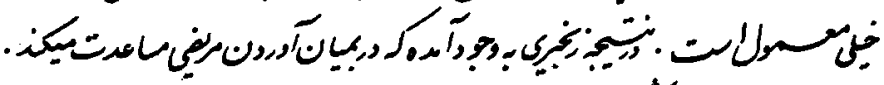

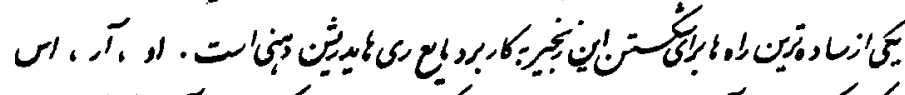

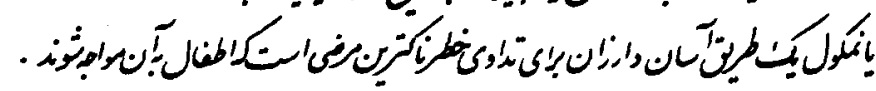


THIS BOOK IS MEANT AS A PRACTICAL MANUAL FOR MOTHERS \& CHILDREN. WE ARE OPTIMISTIC THAT IT CAN ALSO PROVE TO BE A VALUABLE RESOURCE FOR PHYSICIANS, LADY HEALTH VISITORS AND ALL OTHERS INTERESTED IN THE PREVENTION OF. ILLNESS.

IN THE AFGHAN REFUGEE VILLAGES, INFECTIOUS DISEASES ARE VERY COMMON, TOGETHER WITH INADEQUATE NUTRITION, AND POOR ENVIRONMENTAL AND PERSONAL HYGIENE. A CYCLE HAS BEEN CREATED THAT CONTINUES TO FOSTER ILL-HEALTH.

ONE OF THE MOST SIMPLE WAYS TO BREAK THIS CYCLE IS THROUGH THE USE OF ORAL REHYDRATION THERAPY. O. R. S, OR NIMKOL, IS A LOW COST, EASY WAY TO TREAT ONE OF THE MOST LIFE - THREATENING DISEASES THAT CHILDREN FACE. 


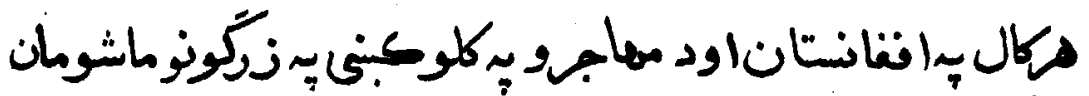

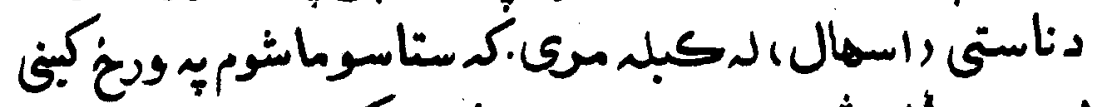

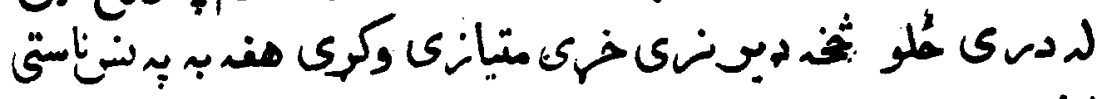
اختّ وى . لمكر

In Afghanistan and in the refugee camps thousands of children are dying of diarrhea every year.

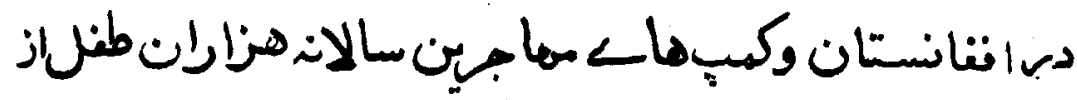

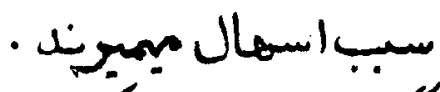

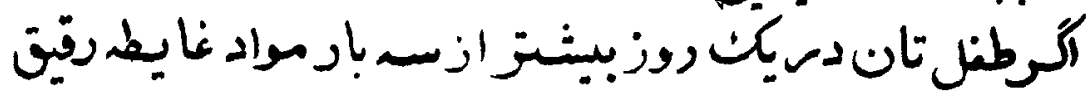

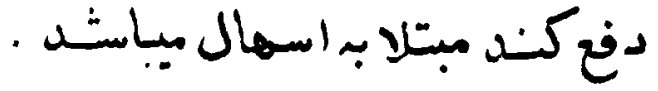





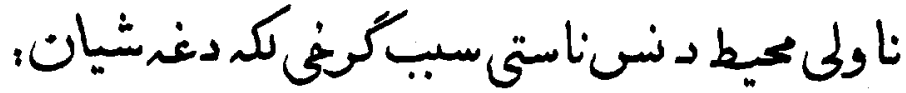

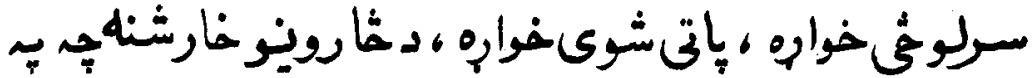

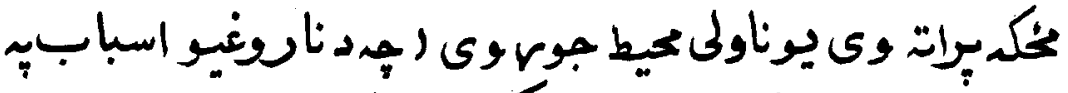

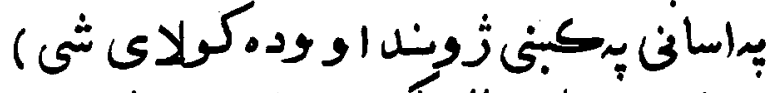

Diarrhea is caused by a dirty environment. Things like uncovered food, spilled food and animal droppings on the ground make up a dirty environment. Always keep your environment clean \& remember that the Prophet said that to be clean is a true virtue.

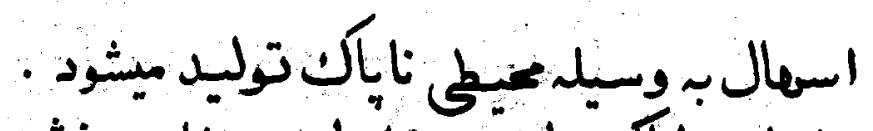

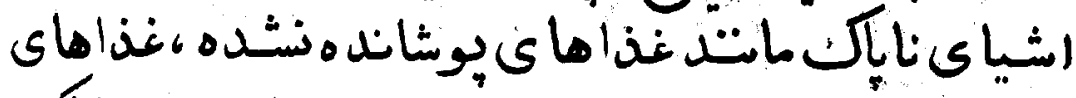

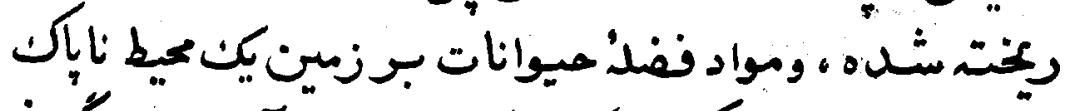

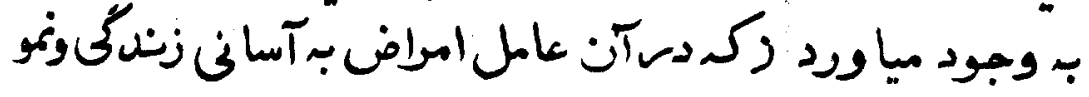

$$
\text { ميتواند) }
$$

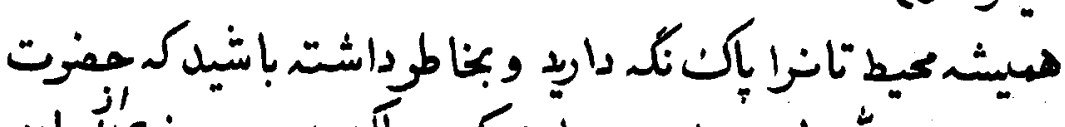

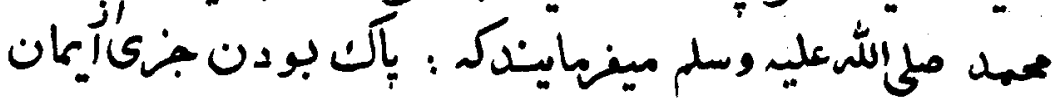




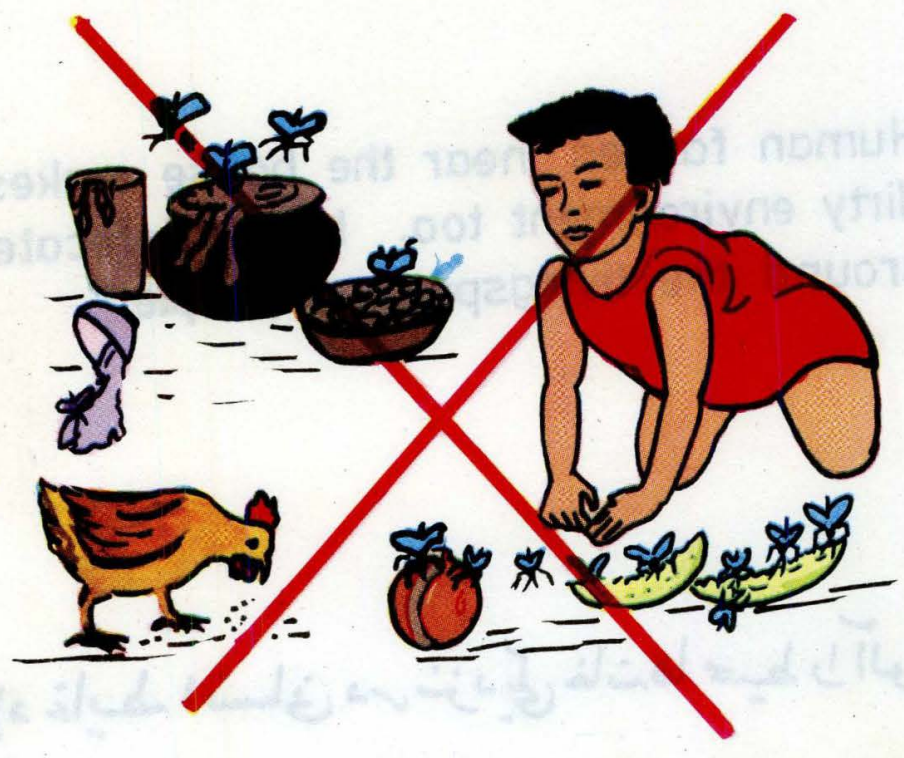




$$
\begin{aligned}
& \text { كورت نزدى دانسانغايط مواد هم نا ولى بهاريبـيال جوروى . }
\end{aligned}
$$

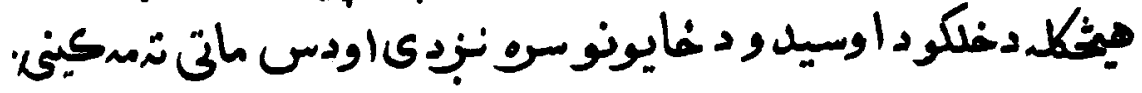

Human faeces near the house makes a dirty environment too. Never defecate around the livingspace of people.

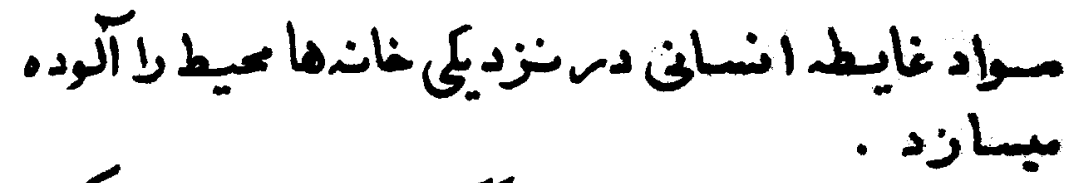

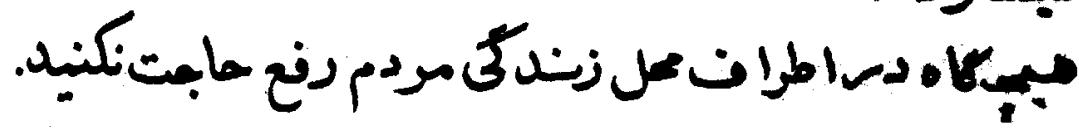




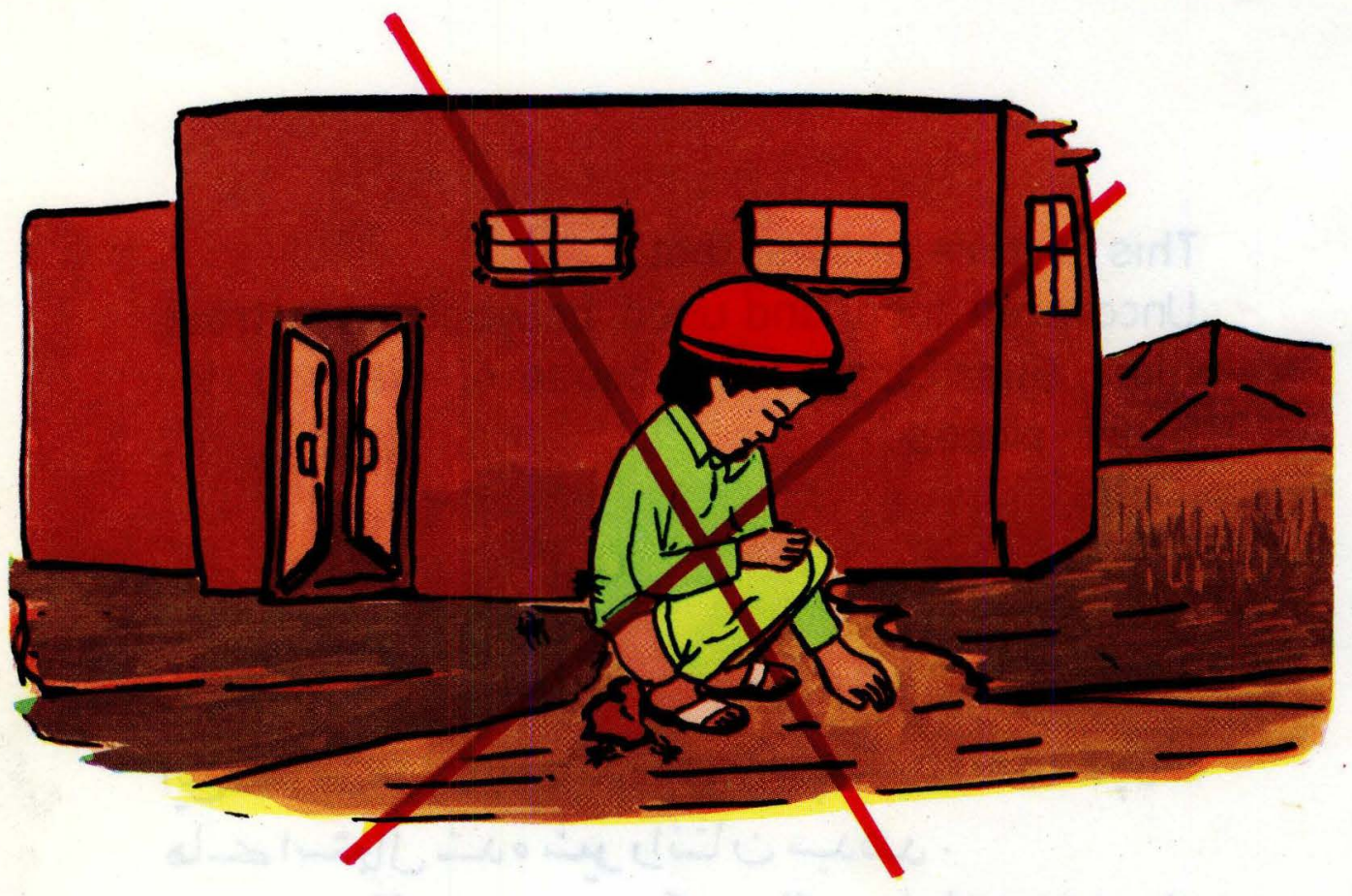




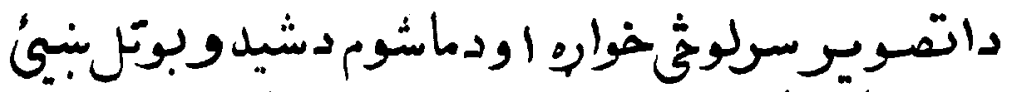

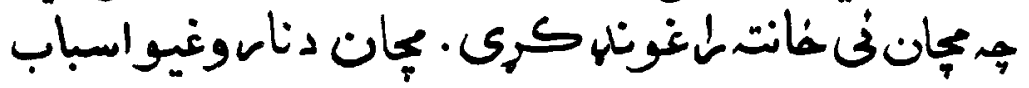

$$
\begin{aligned}
& \text { نوروخايونوتخهبر وى . }
\end{aligned}
$$

This picture shows that:

Uncovered food and u'sed babybottles attract flies. Flies spread the cause of disease to other places.

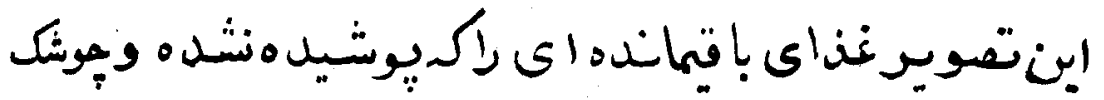

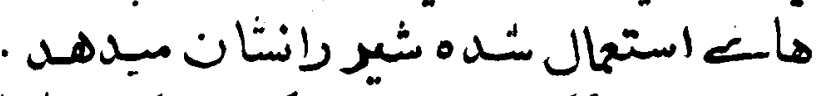

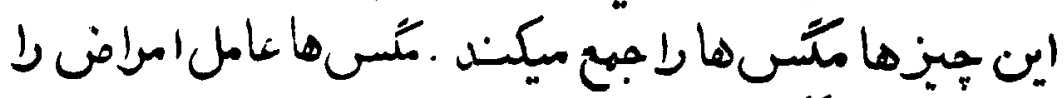

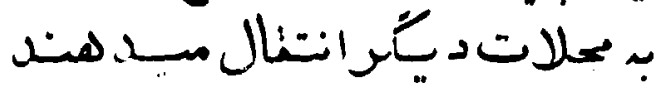




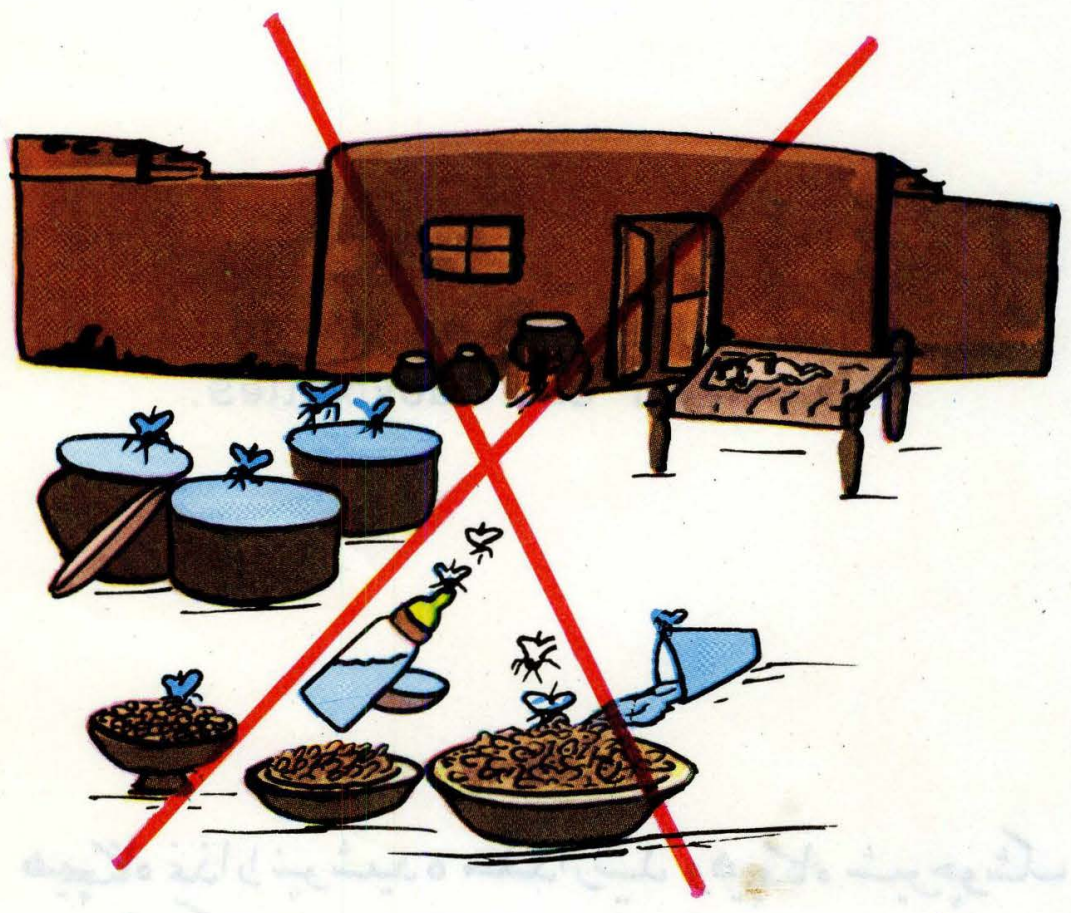




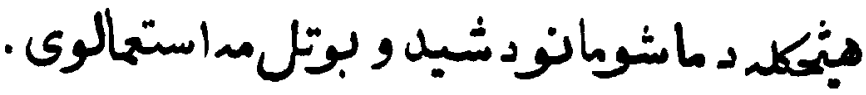

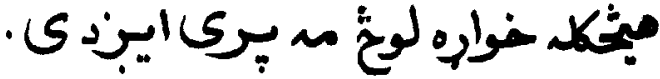

Never leave food uncovered.

And never use babybottles.

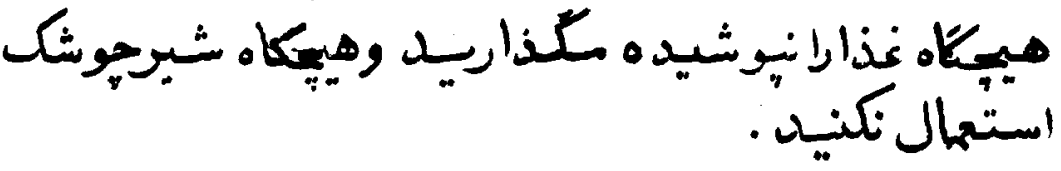




$$
\alpha_{0}^{2}
$$




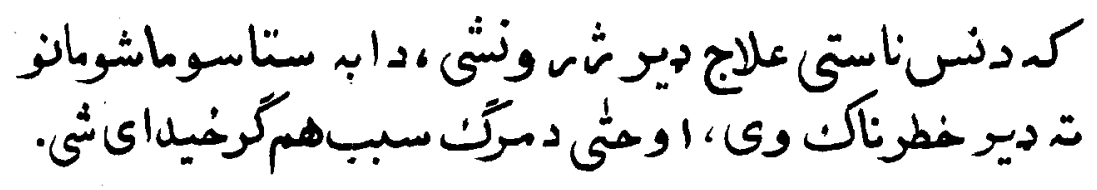

If diarrhea is not treated immediately, it will be dangerous for your child and she/he can even die.

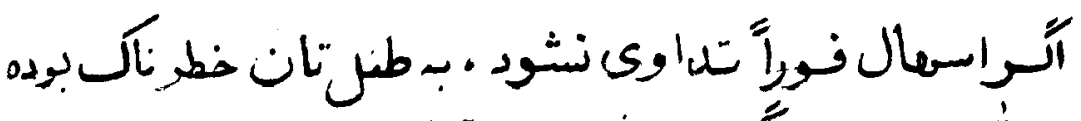

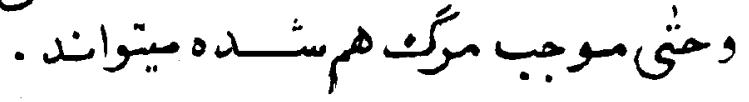




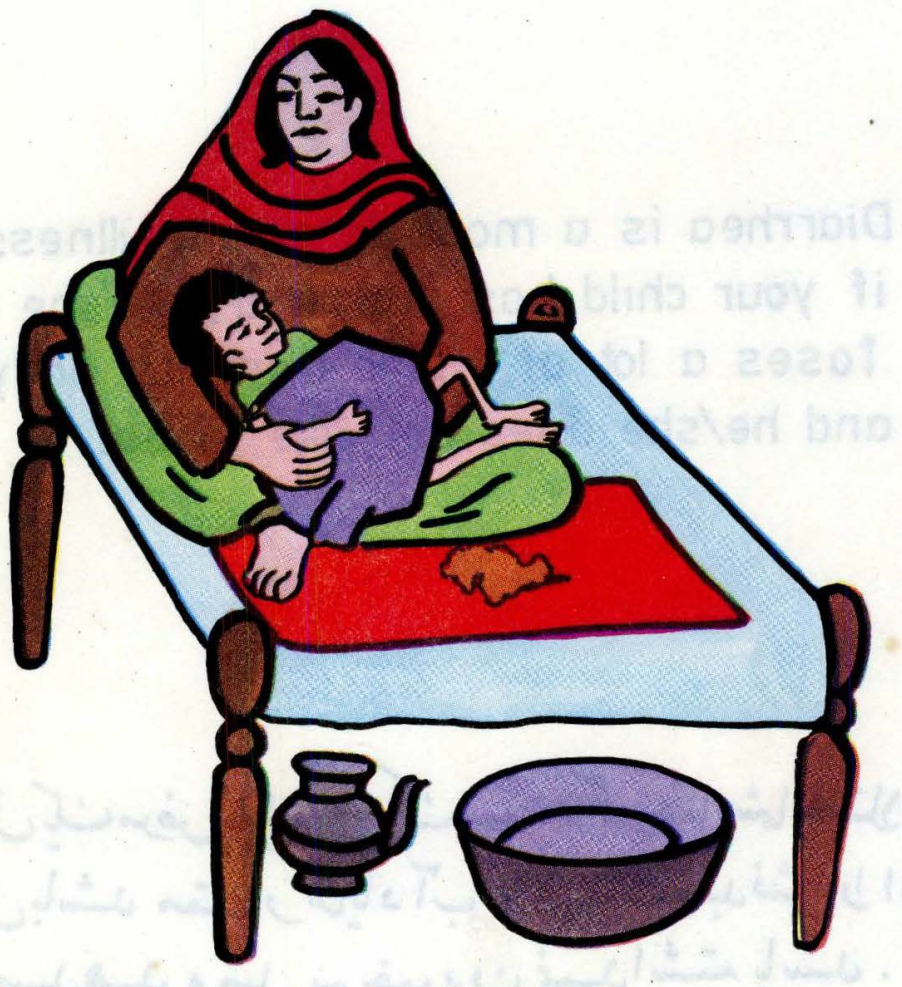




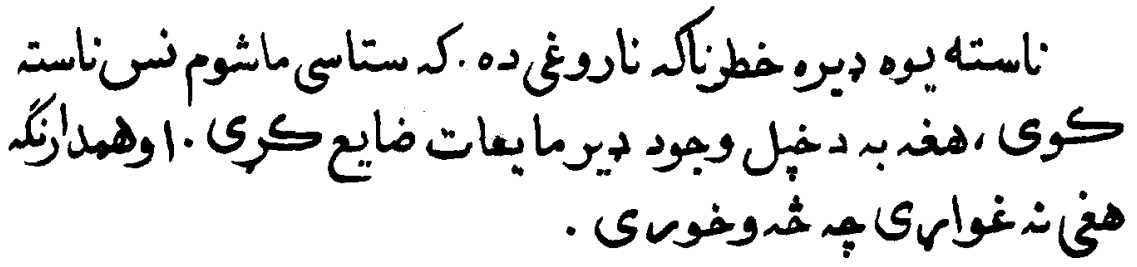

Diarrhea is a most dangerous illness; if your child has diarrhea, he/she toses a lot of water from its body. and he/she does not like to eat.

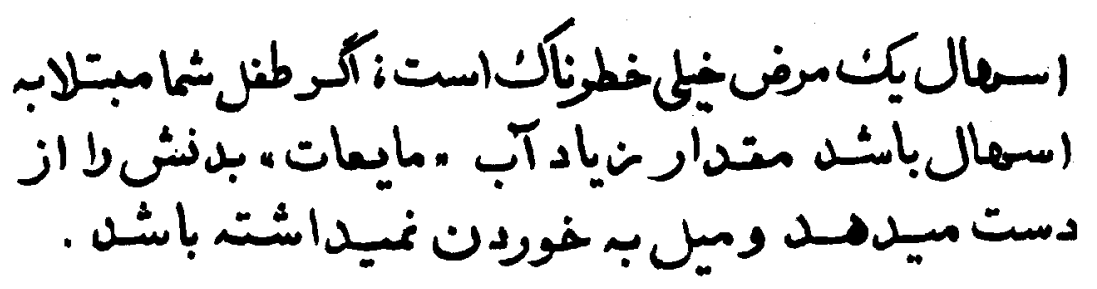




$$
\text { एos }
$$




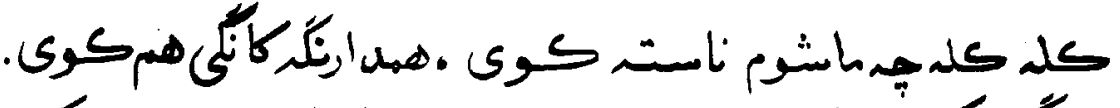

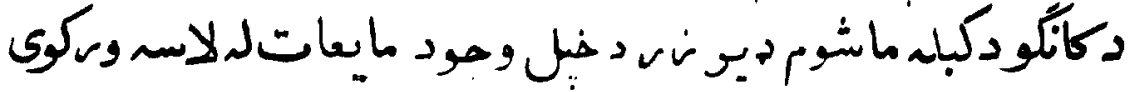

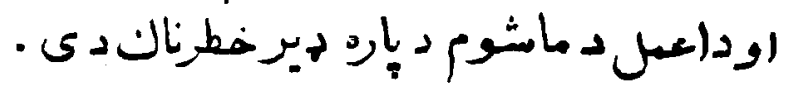

Sometimes, when a child has diarrhea, he/she vomits too. Because of this vomiting, the child loses the water (fluids) from its body very quickly, and this is very dangerous for the child.

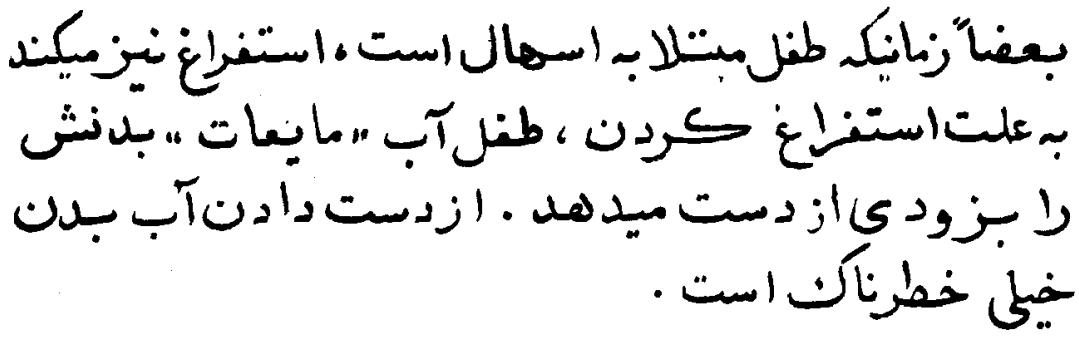




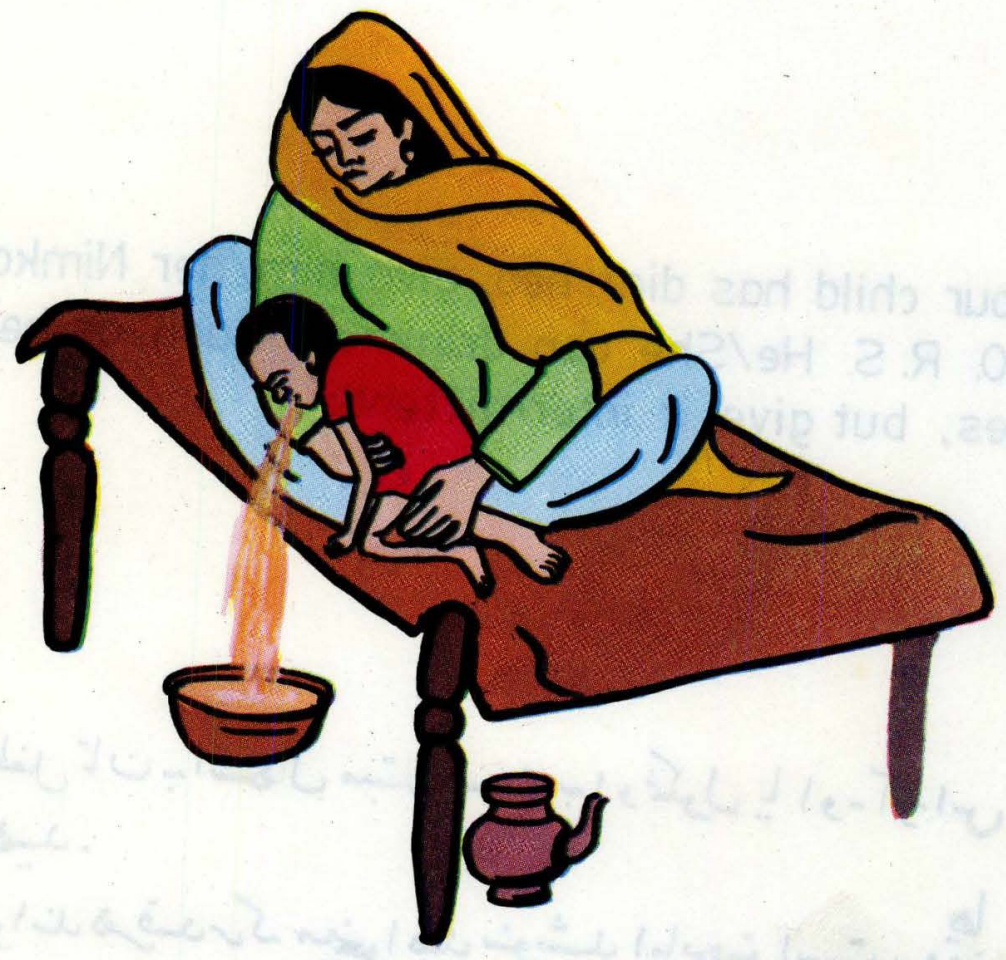




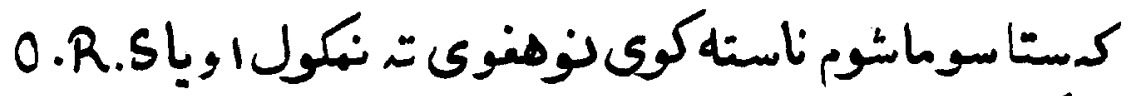

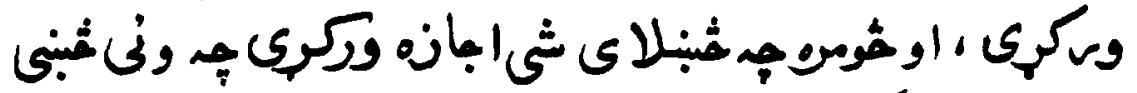

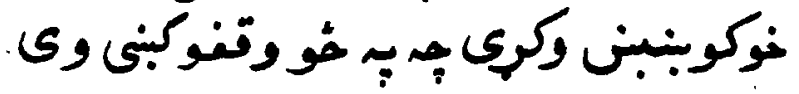

If your child has diarrhea, give him/her Nimkol or 0. R.S. He/She can drink as much as he/she likes, but give it intermittently.

$$
\begin{aligned}
& \text { اكرطفل تان بـاسمال مبّتلا استبـا ونمكول يا او-آر-اس }
\end{aligned}
$$

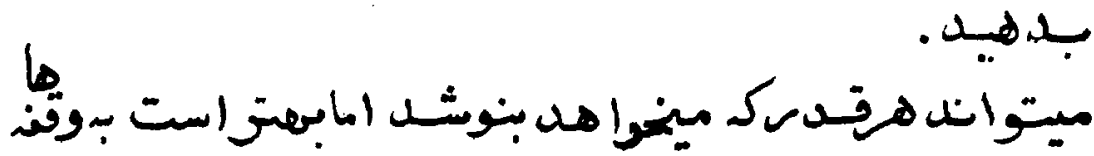

$$
\begin{aligned}
& \text { بـ طنل نمكول بدهيد . }
\end{aligned}
$$





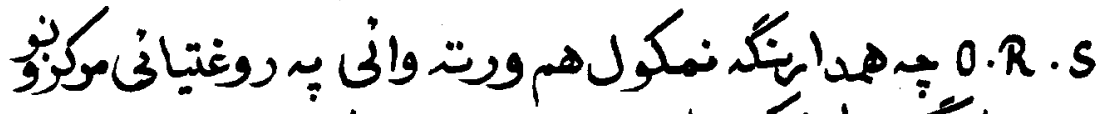

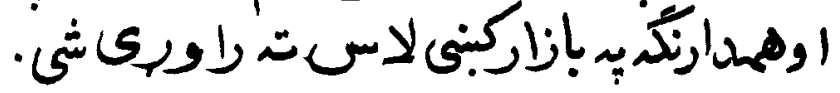

O. R. S which is also called Nimkol, is available in the B.H.U. or in the bazaar.

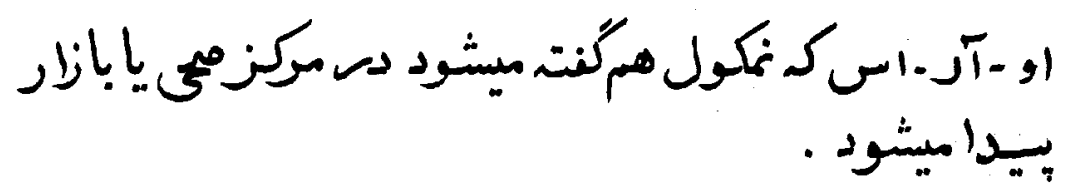




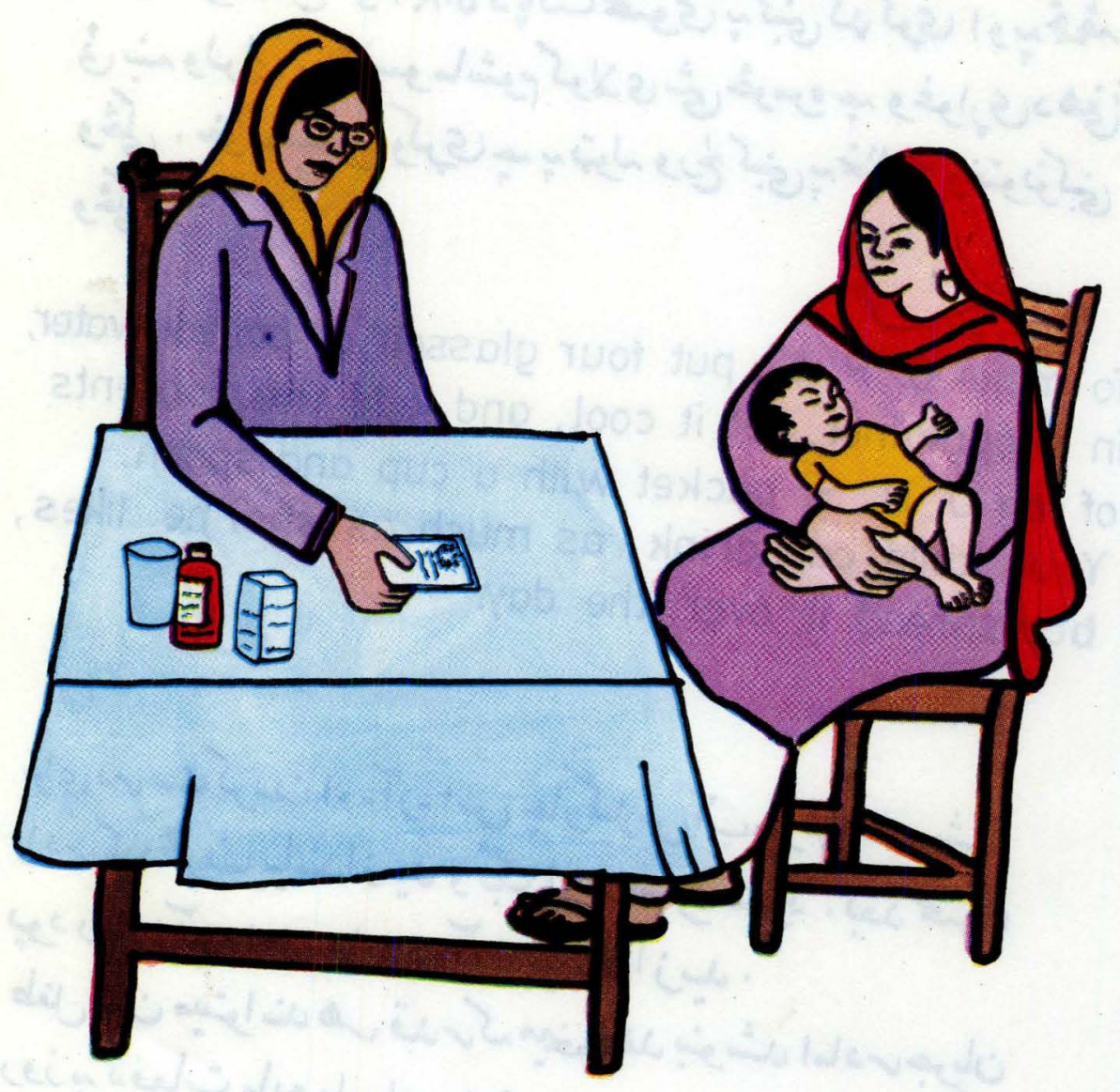




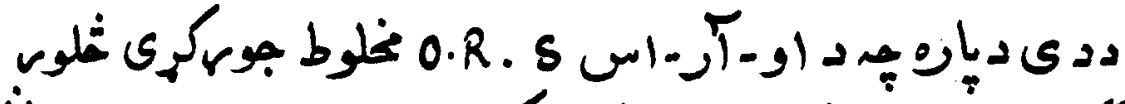

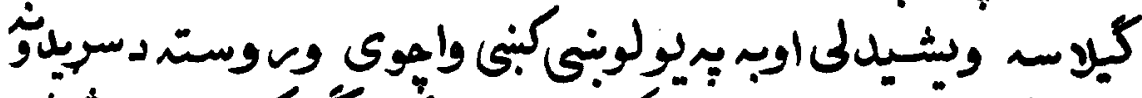

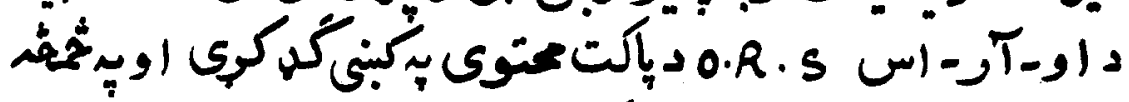

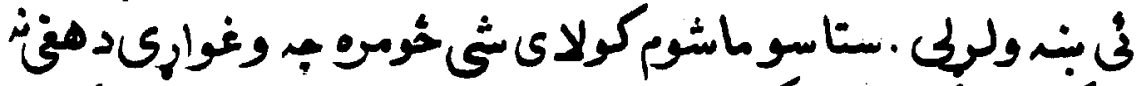

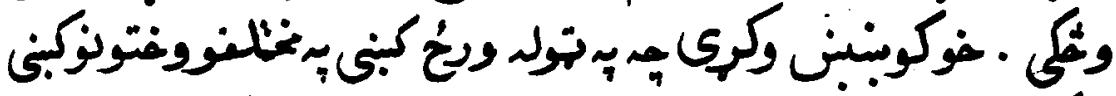

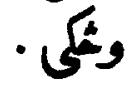

To make 0 . R. S.,put four glasses of boiled water, in a container, let it cool, and add the contents of an O. R. S. packet with a cup and spoon. Your child can drink, as much as she/he likes, but spread it over the day.

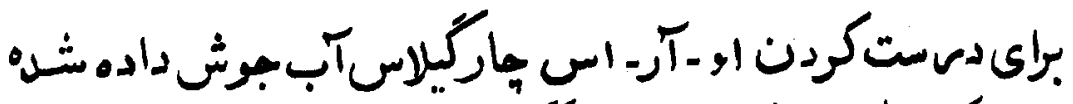

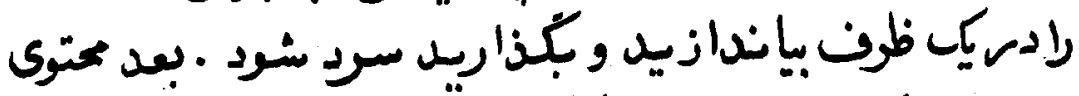

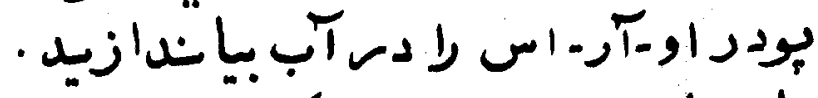

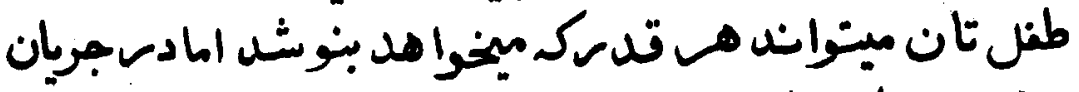

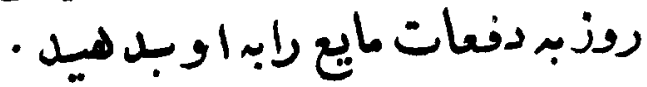




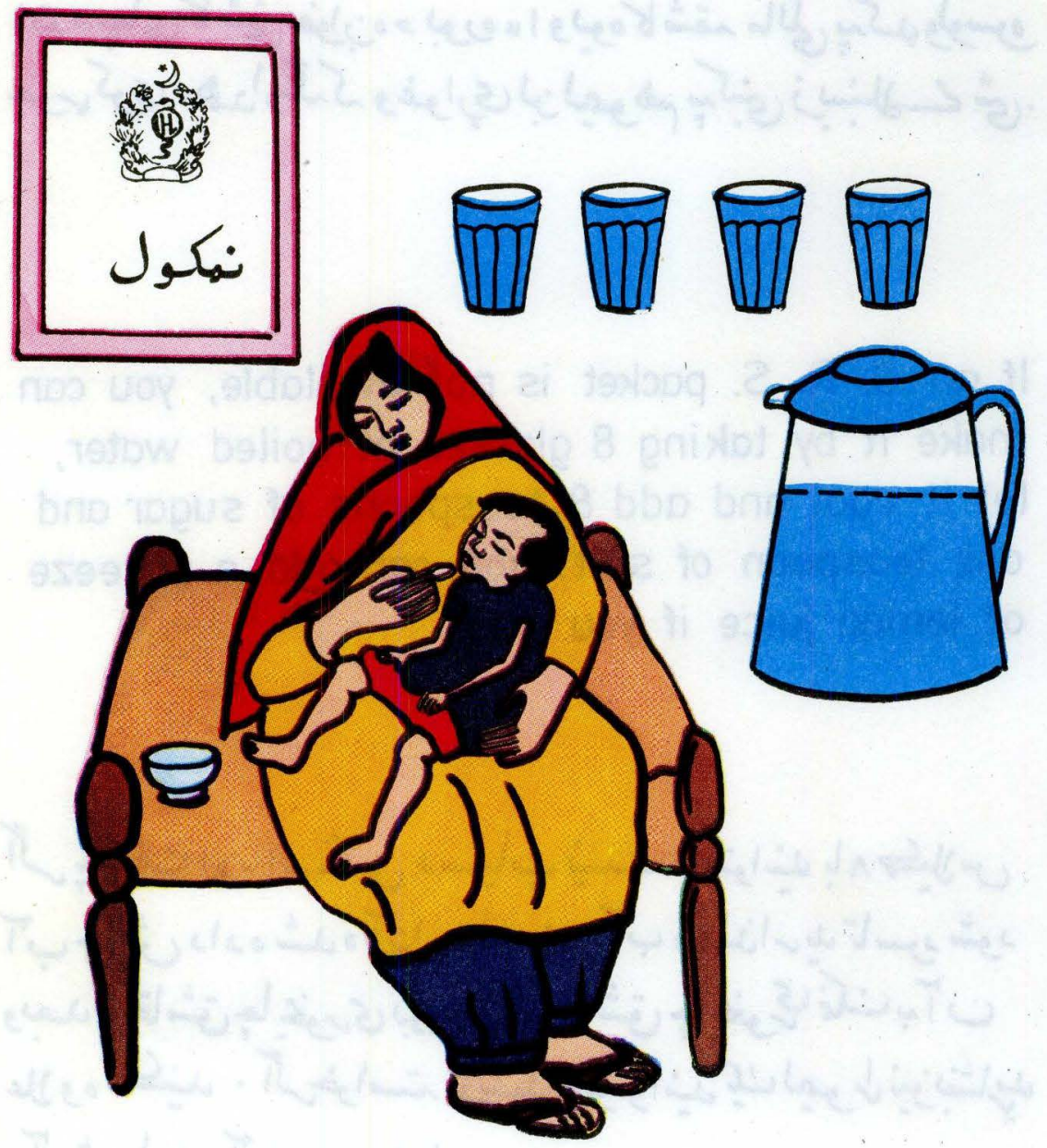




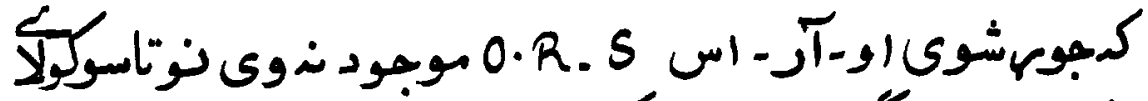

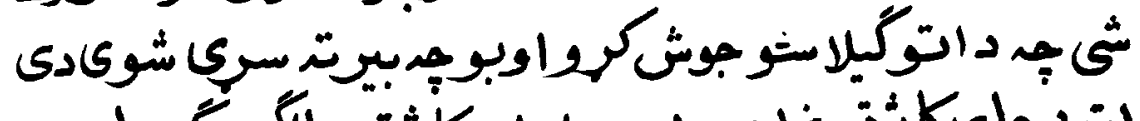

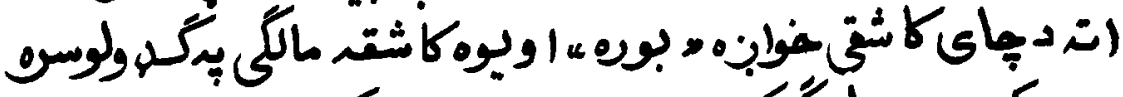

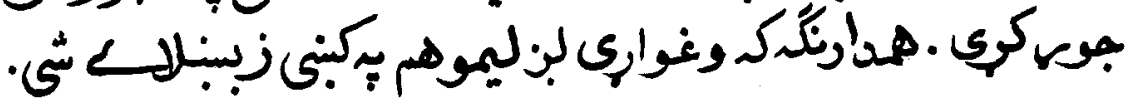

If an O.R. S. packet is not available, you can make it by taking 8 glasses of boiled water, let it cool and add 8 teaspoons of sugar and one teaspoon of salt. You can add a squeeze of lemon juice if you like.

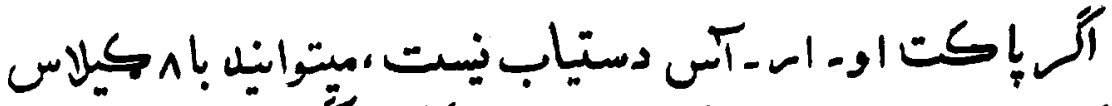

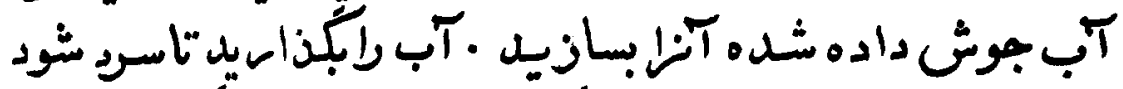

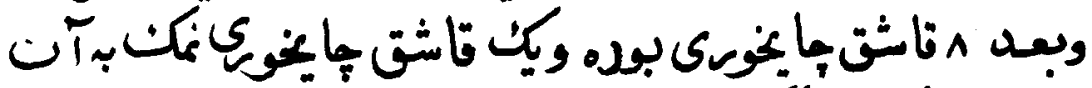

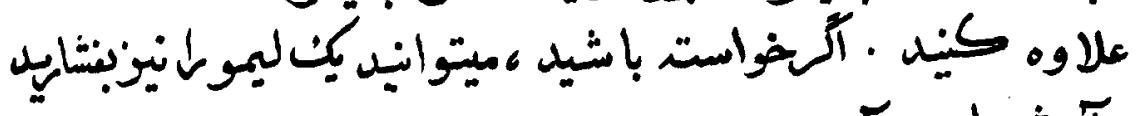

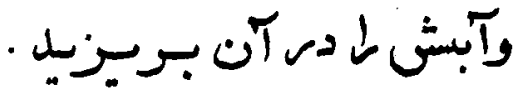



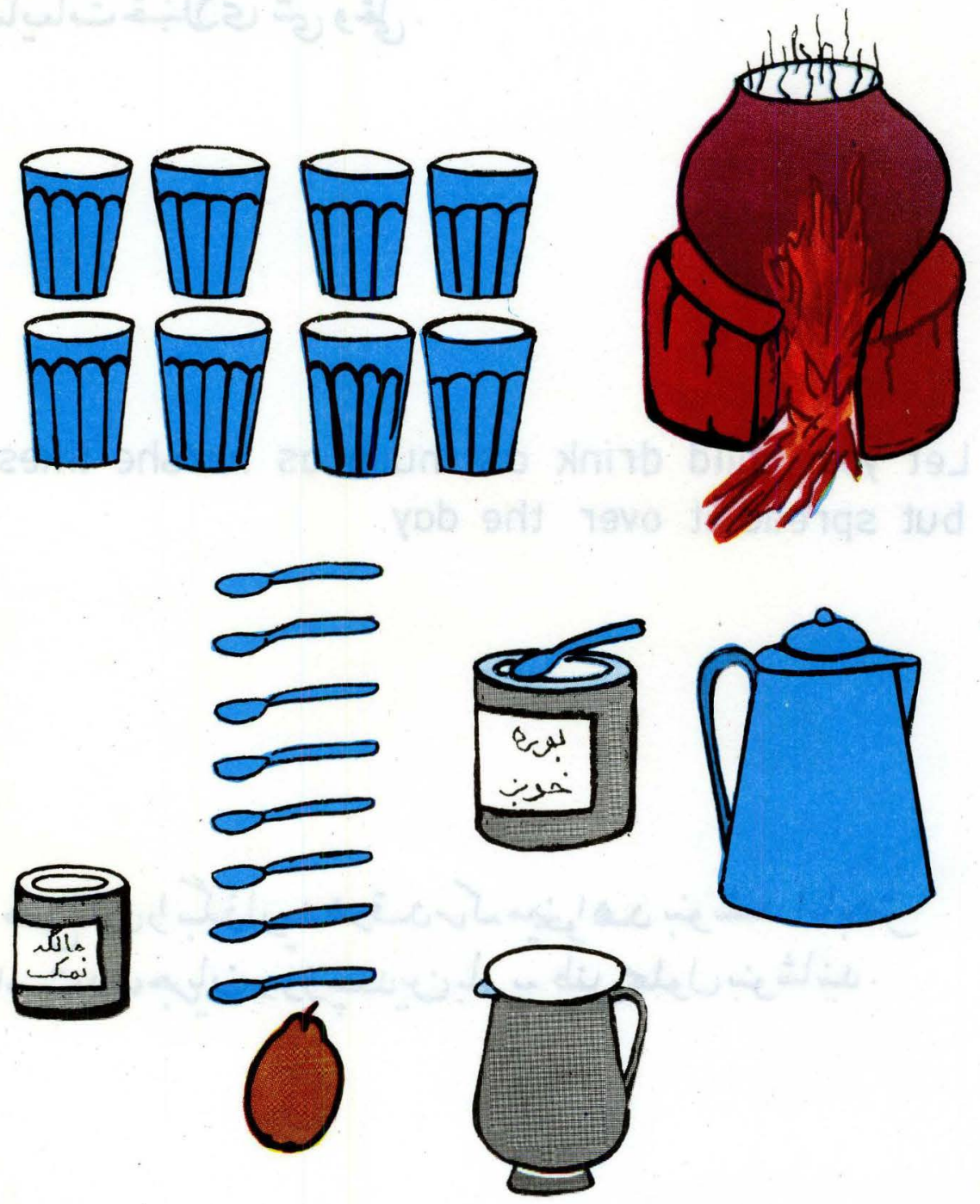


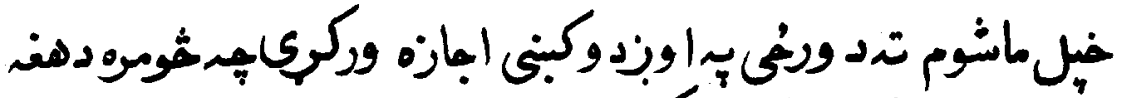

$$
\begin{aligned}
& \text { مايعات شُبنلاى شتى وشئى . }
\end{aligned}
$$

Let your child drink as much as he/she likes, but spread it over the day.

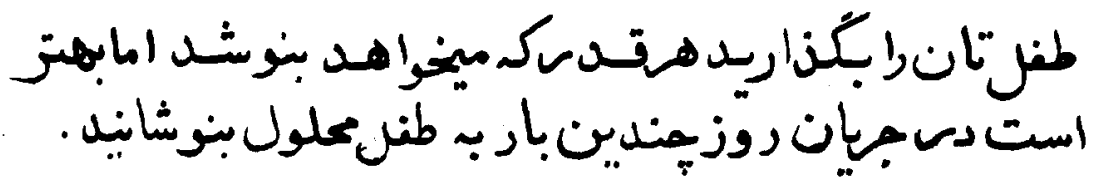




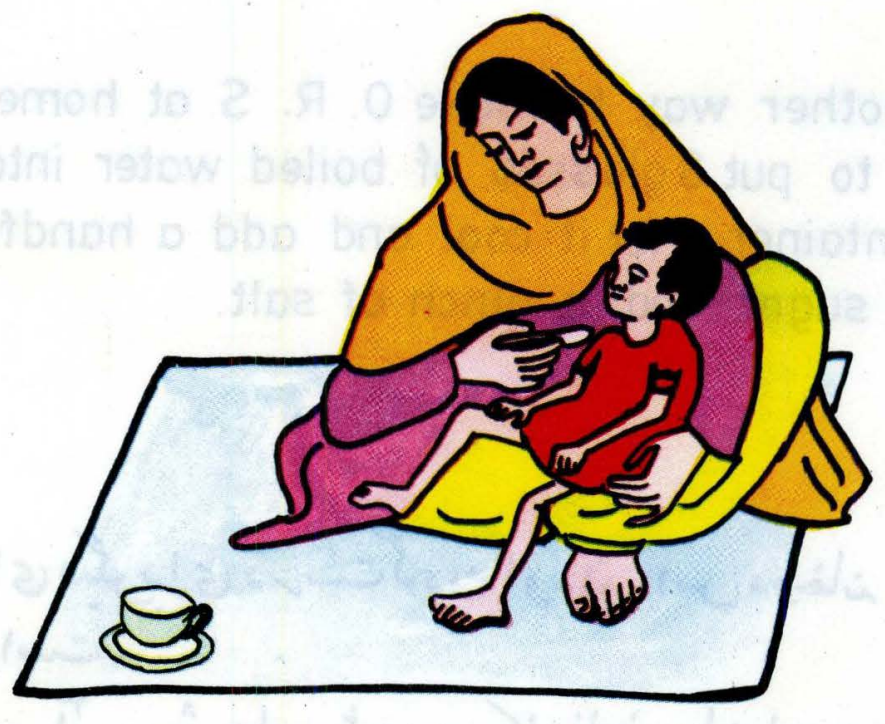




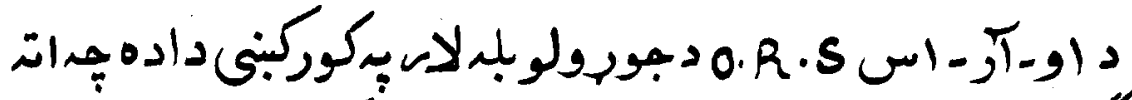

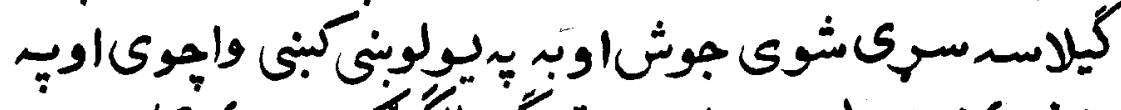

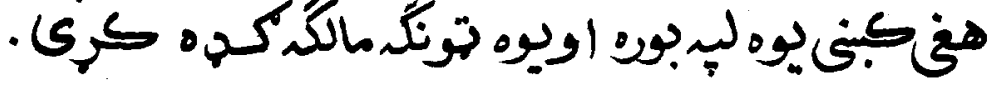

Another way to make 0 . R. S. at home is to put 8 glasses of boiled water into a container, let it cool and add a handful of sugar and a pinch of salt.

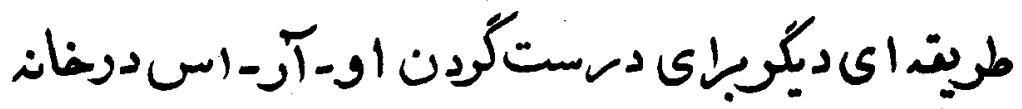

$$
\begin{aligned}
& \text { اينطوراست : }
\end{aligned}
$$

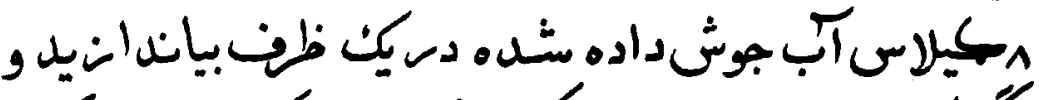

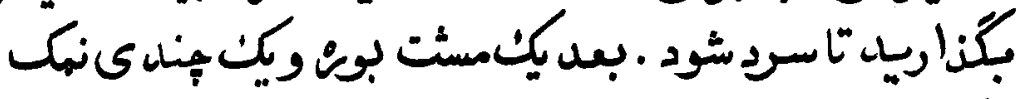

$$
\begin{aligned}
& \text { بآن علاوه كنيد . }
\end{aligned}
$$




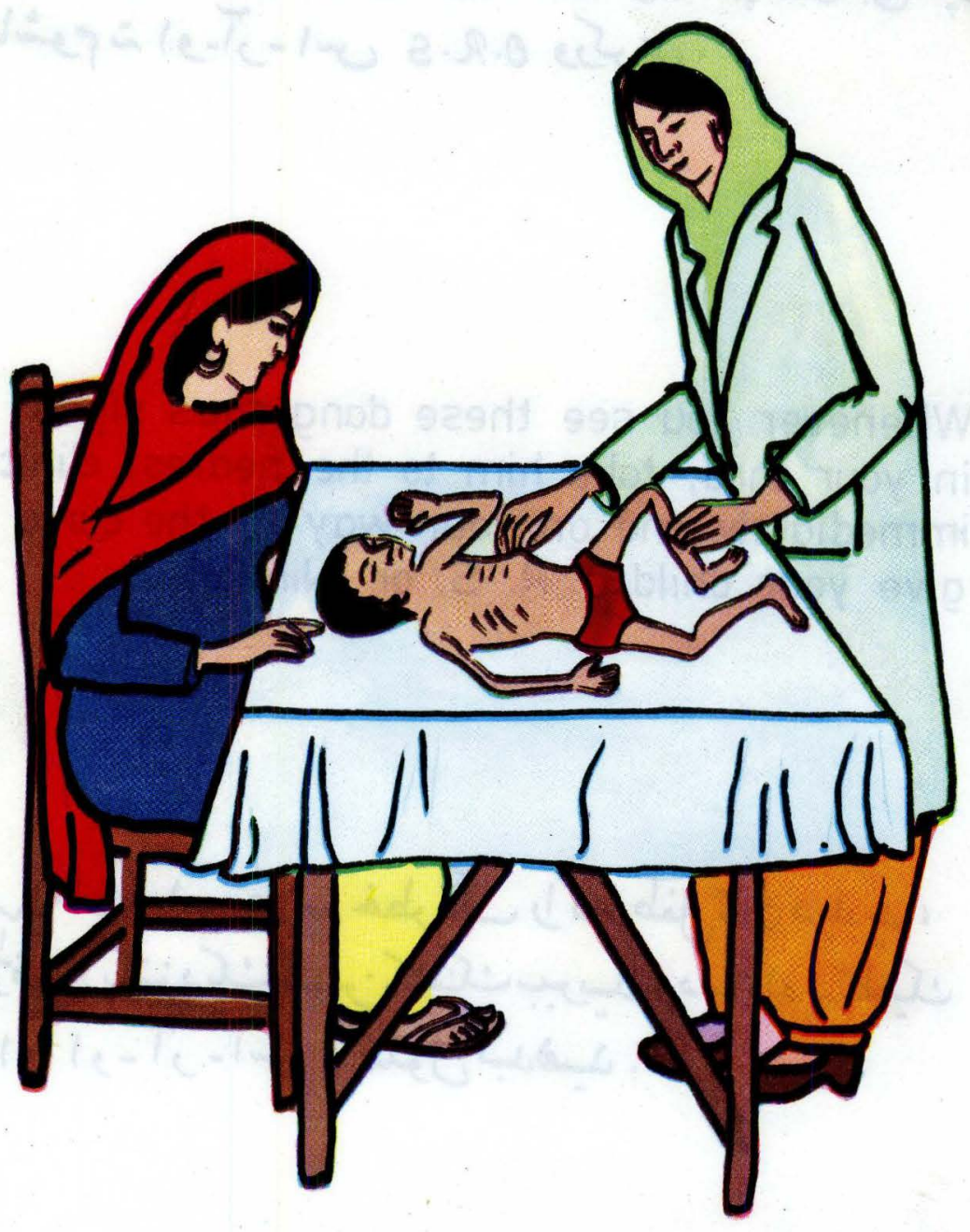




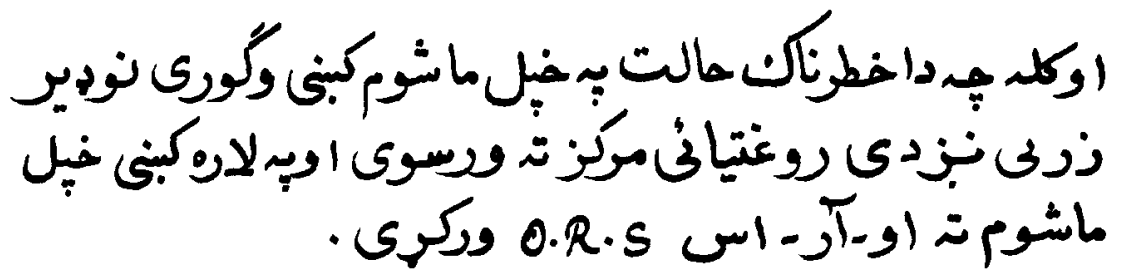

Whenever you see these dangerous signs in your child, take him to the nearest clinic immediately, and on your way to the clinic give your child 0 . R. S. or Nimkol.

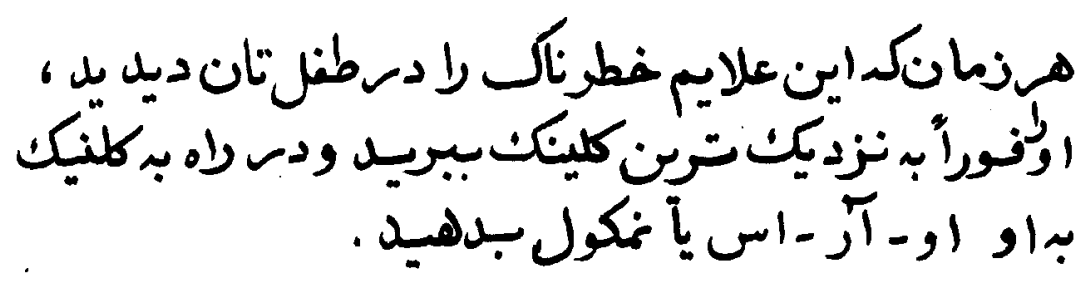




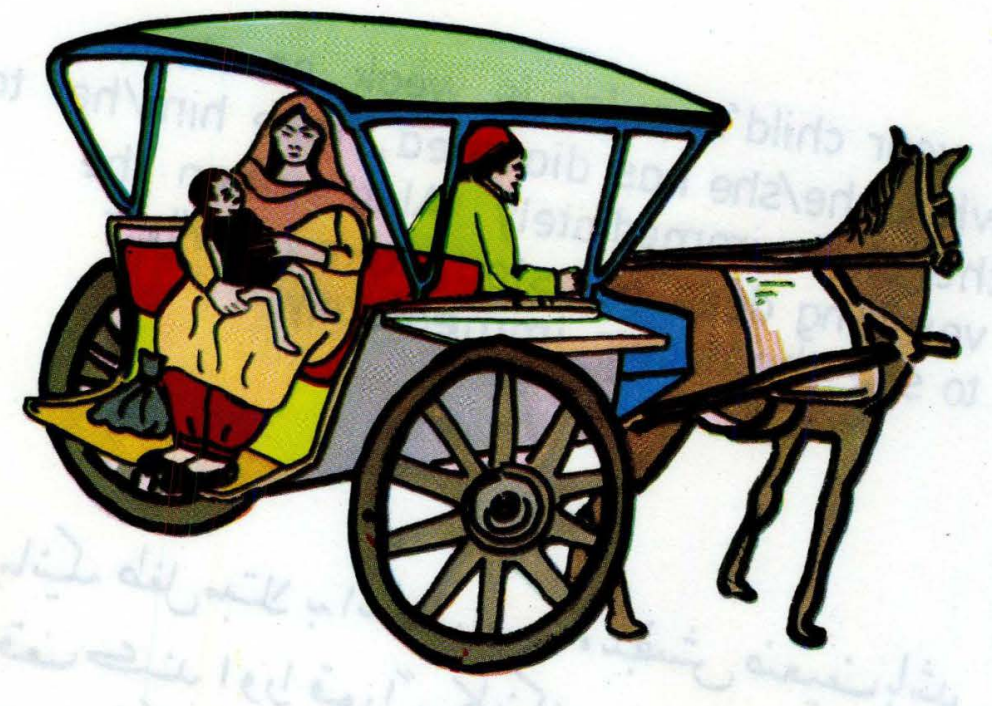




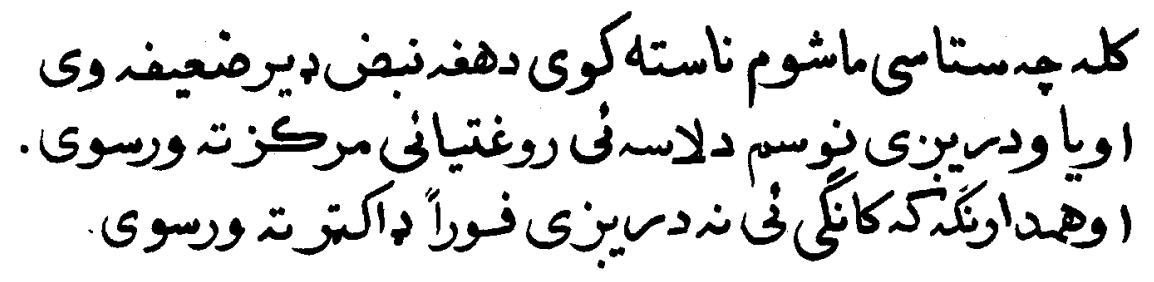

If your child's pulse is weak or stops while he/she has diarrhea, take him/her to the clinic immediately. Also, when the vomiting does not stop, take hım/her to see the doctor immediately.

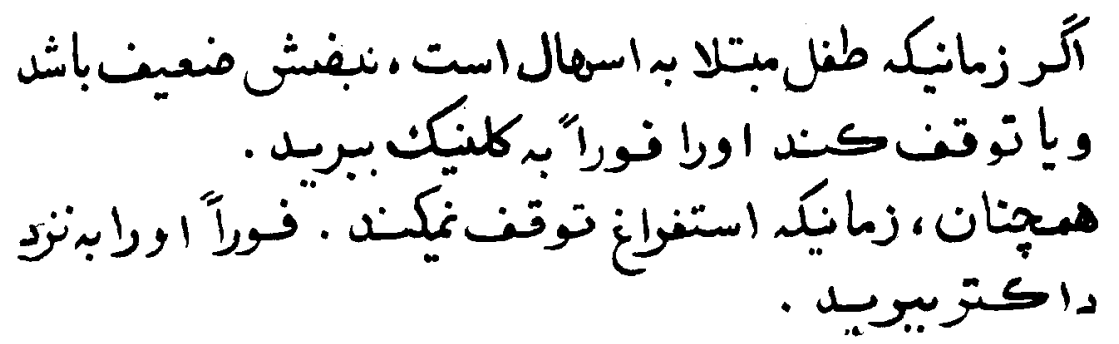




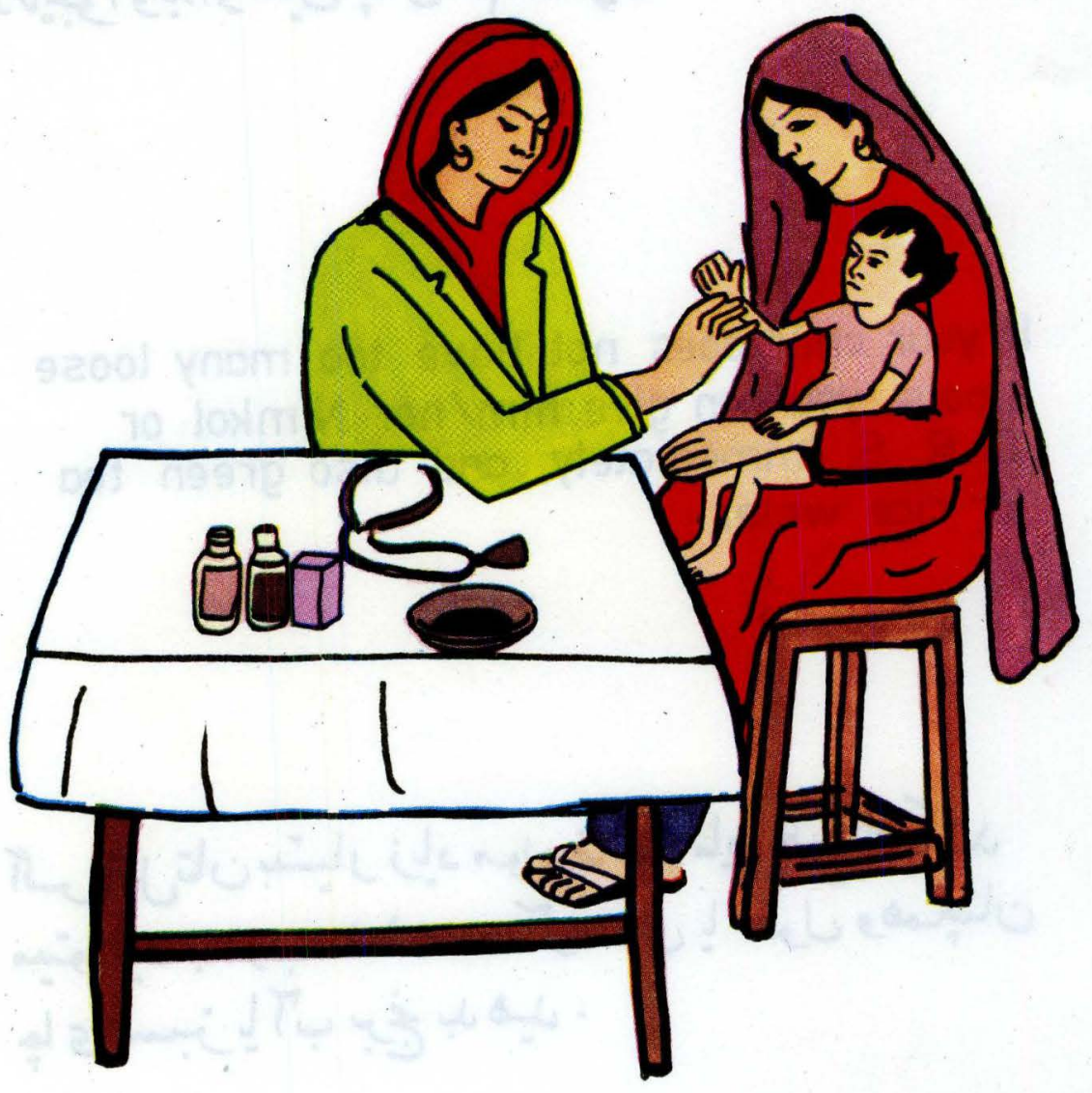




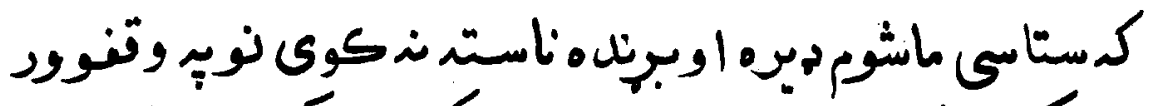

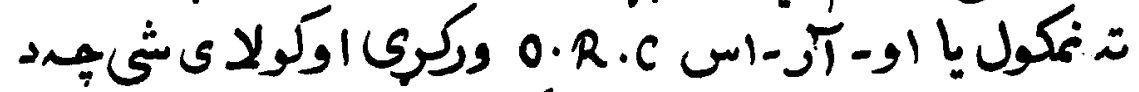

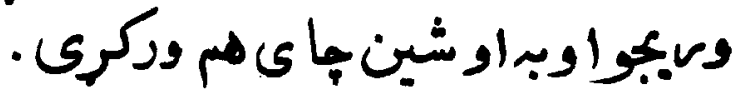

If your child does not have too many loose stools. you can give him/her Nimkol or 0 . R. S. immediately, and also green tea or rice water.

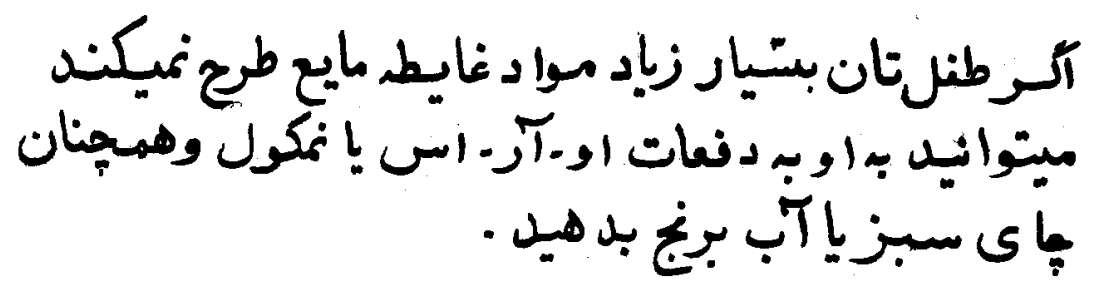




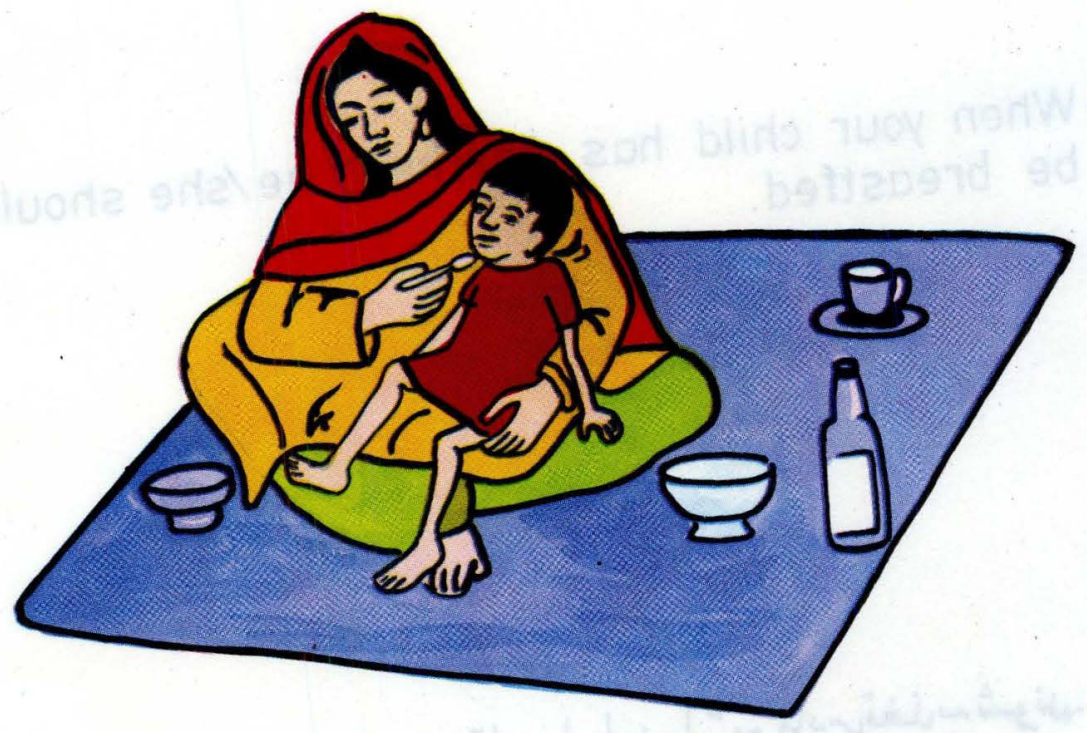




$$
\text { دناستى يـ مودهكبى ماشوم تبإيل موه تى هم وركرى }
$$

When your child has diarrhea, he/she should be breastfed. 


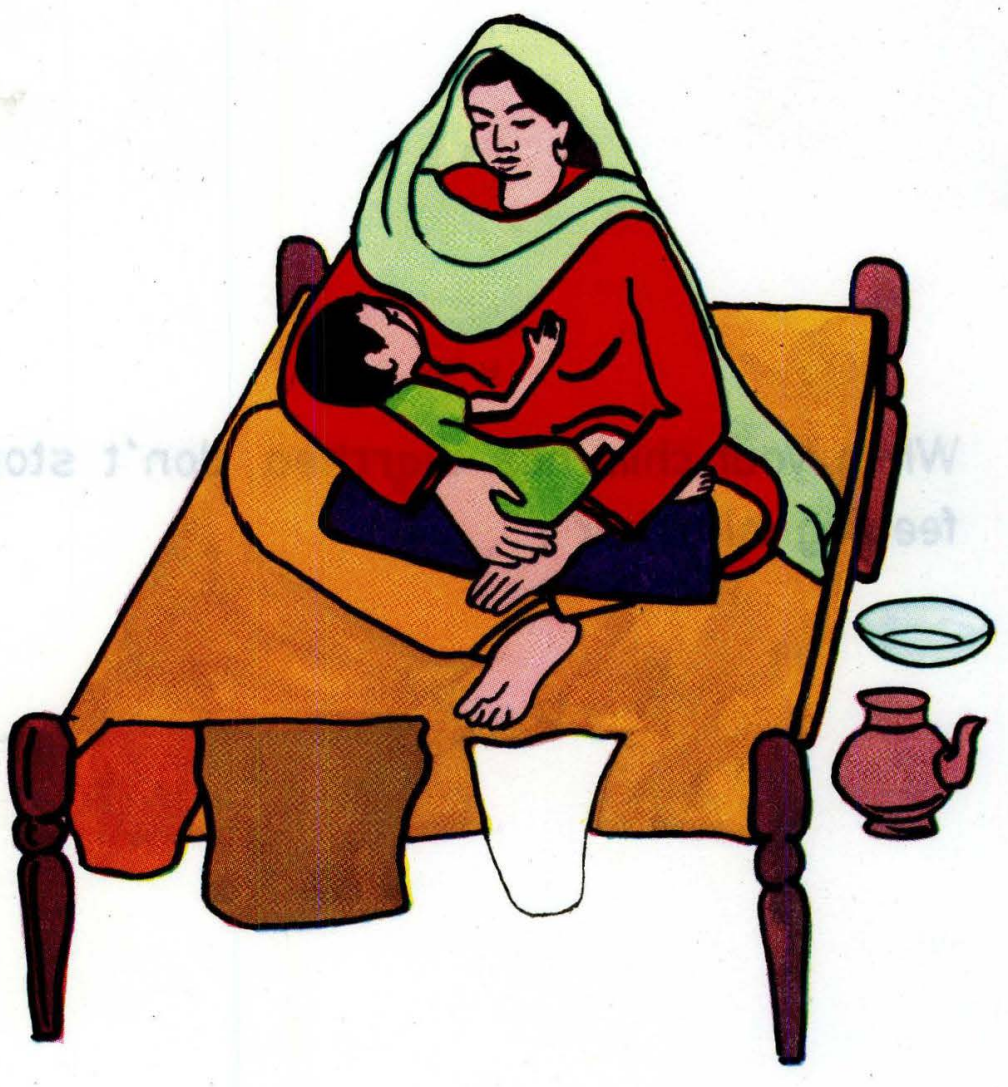


داسهال بـصورتكبنى مب باينتاسود ماشوم خواره ونددهوى

When your child has diarrhea, don't stop feeding him/her

دمواقتات ملاريا غذا داد ادن رابـطنلتان توقت ندهيه .

$r$ 


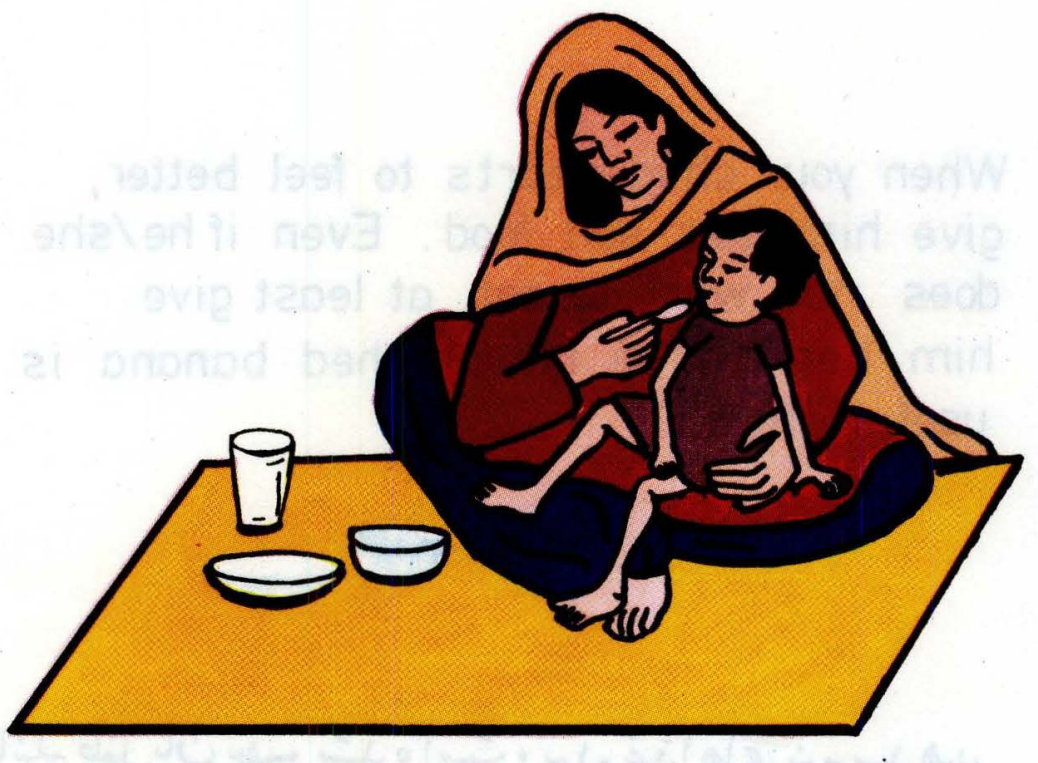




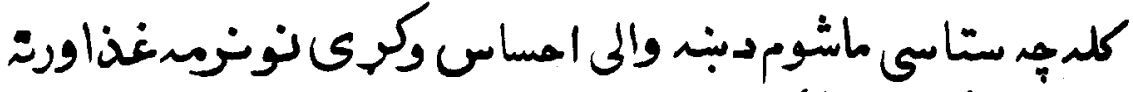

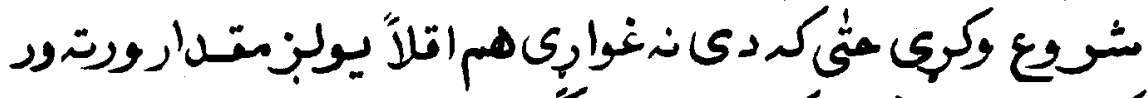

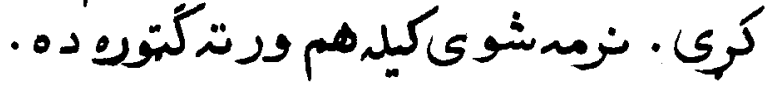

When your child starts to feel better, give him/her soft food. Even if he/she does not want to eat, at least give him/her a little bit. Mashed banana is useful then.

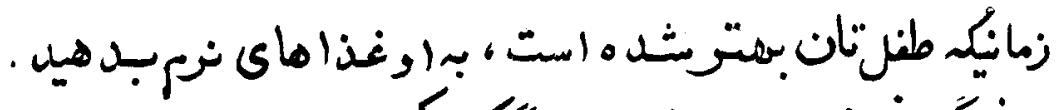

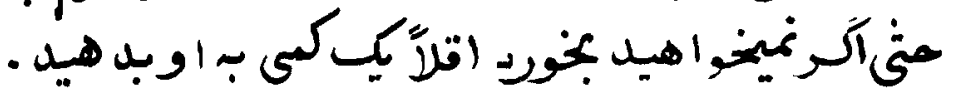

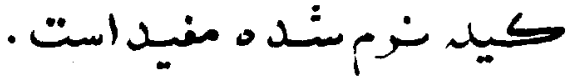





$$
\begin{aligned}
& \text { ماشتوم تد دورثبدى وركول داسهال ن ديخنيوىبمتريت } \\
& \text { مليتده . }
\end{aligned}
$$

\section{Breastfeeding is one of the ways to prevent diarrhea.}

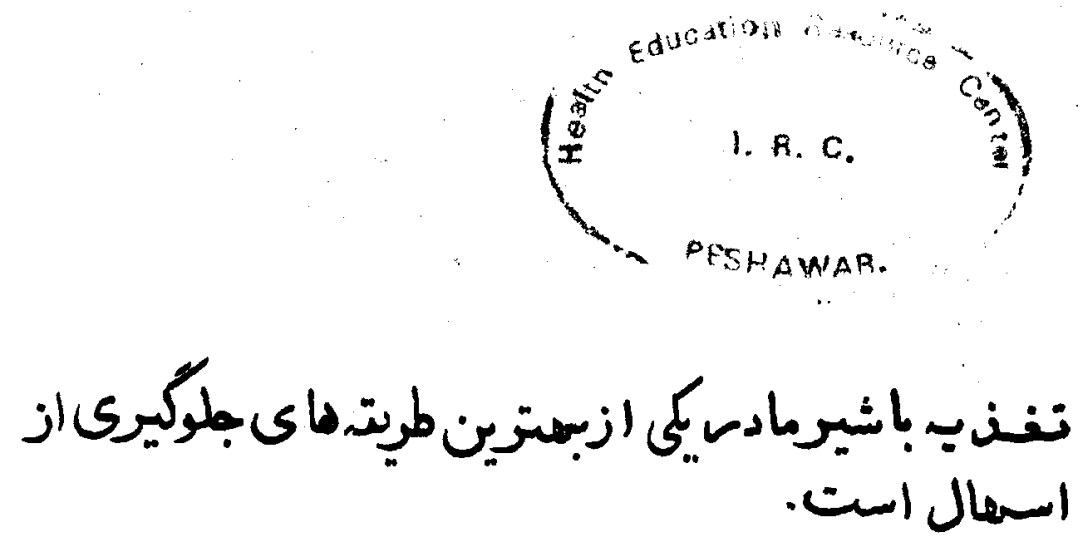




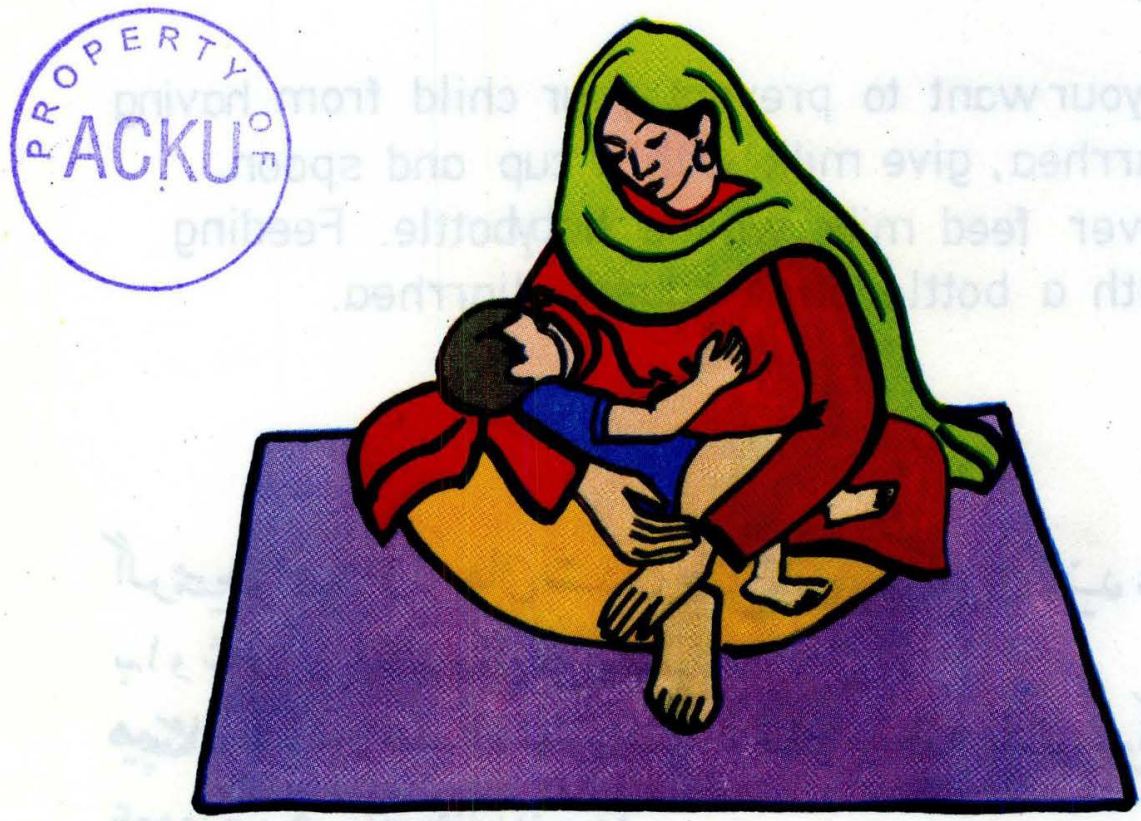




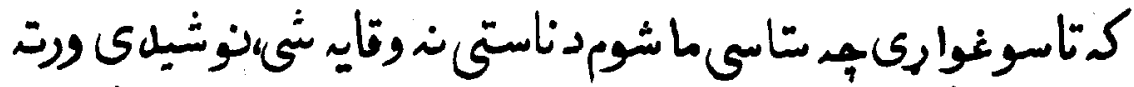

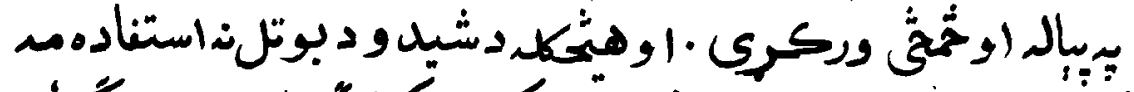

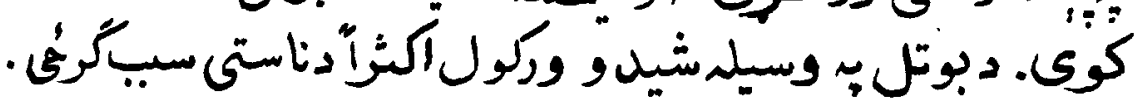

If you want to prevent your child from having diarrhea, give milk with a cup and spoon.

Never feed milk with a babybottle. Feeding with a bottle often causes diarrhea.

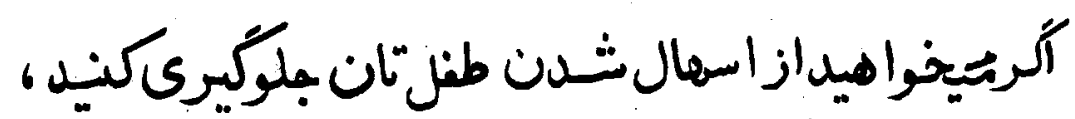

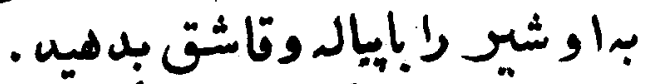




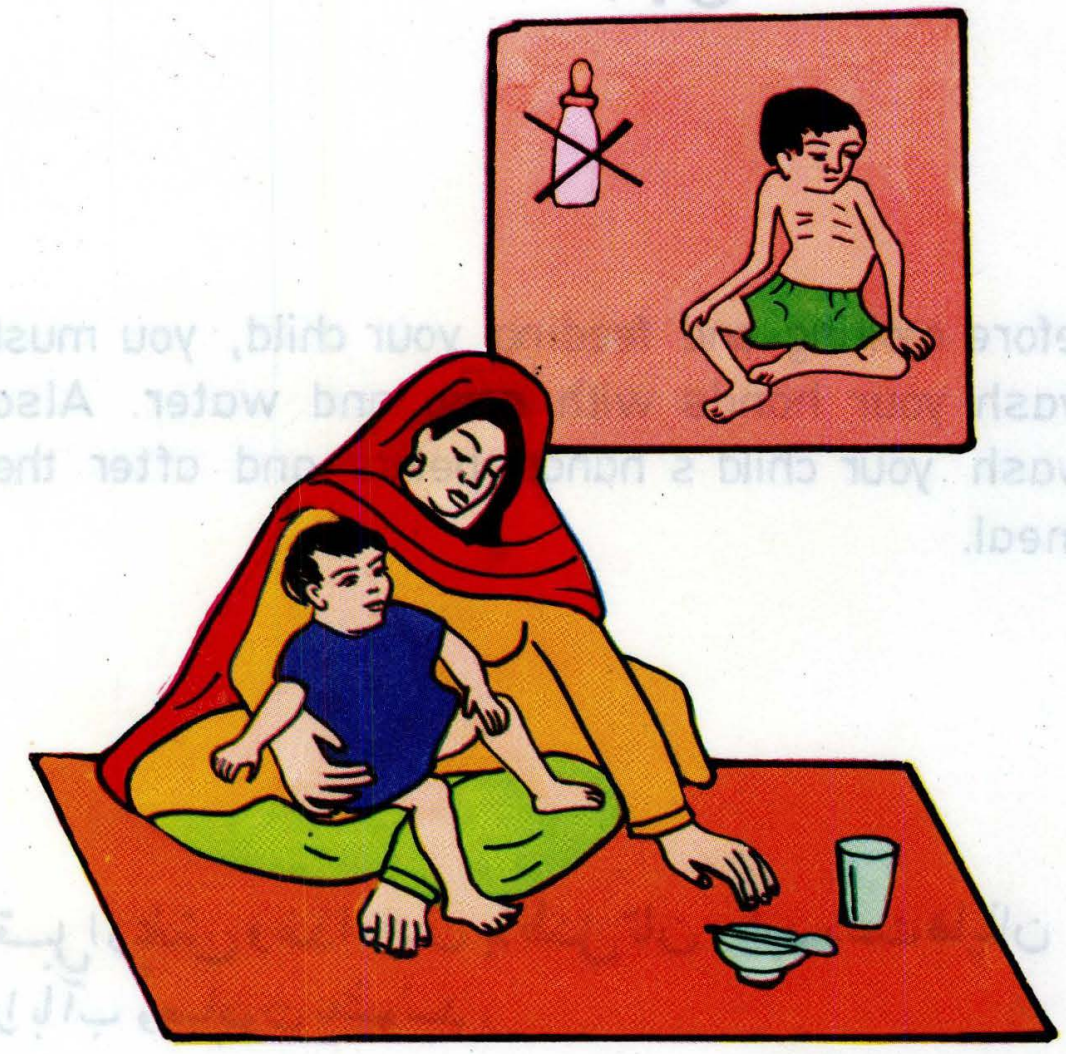




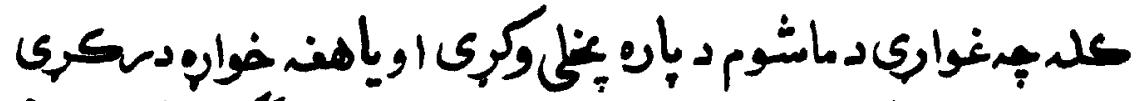

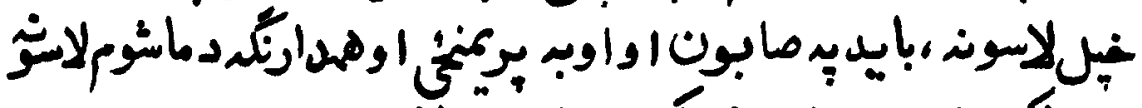

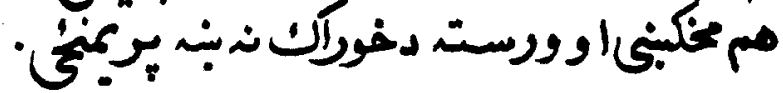

Before cooking and feeding your child, you must wash your hands with soap and water. Also wash your child's hands before and after the meal.

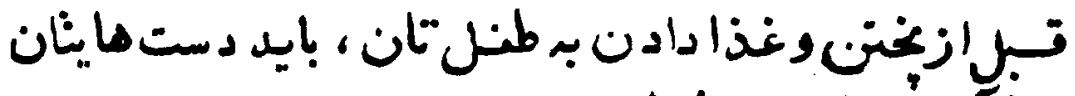

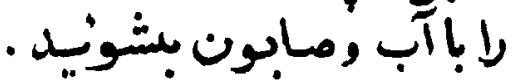

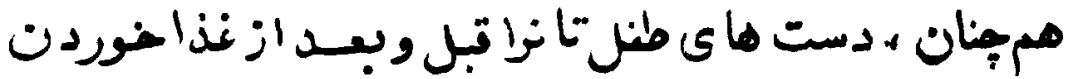

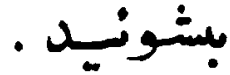

$$
\text { irf, }
$$




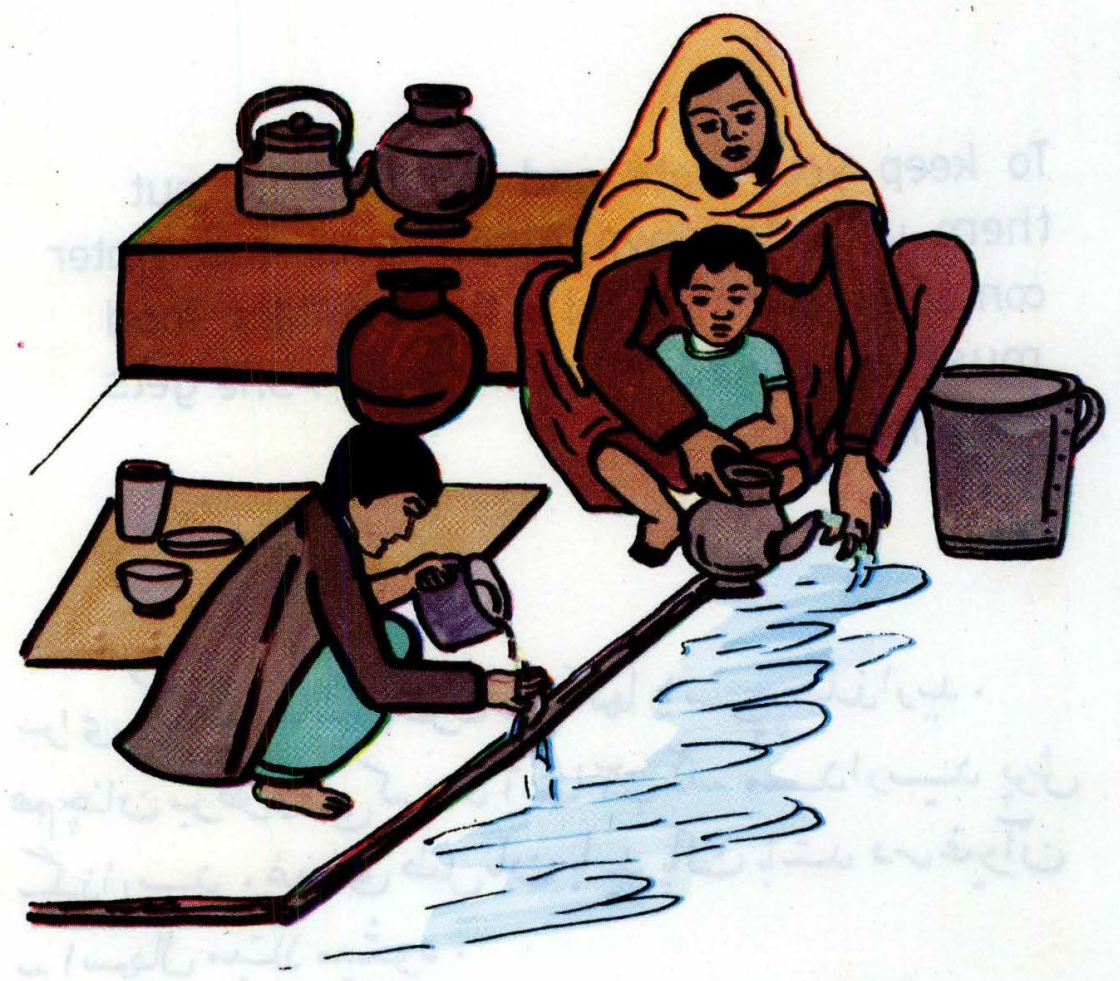




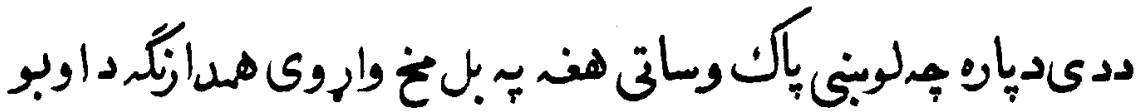

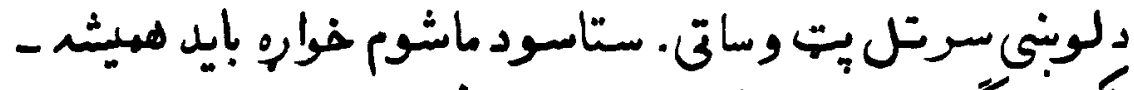

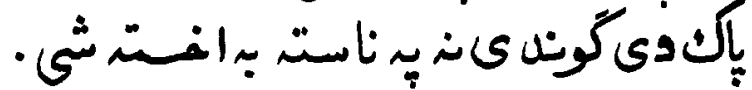

To keep your pots and pans clean, put them up side down. Also, cover the water container with a lid. Your child's food must be clean, otherwise he/she gets diarrhea.

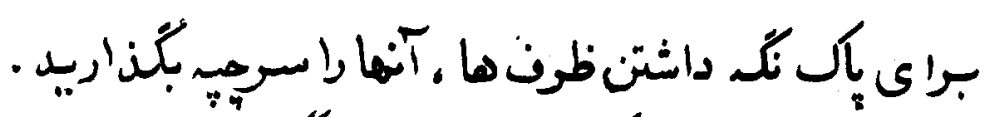

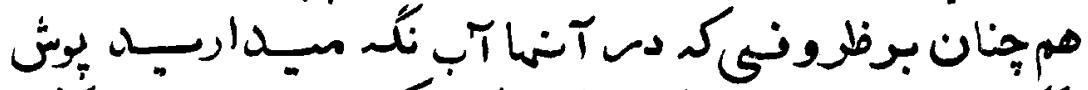

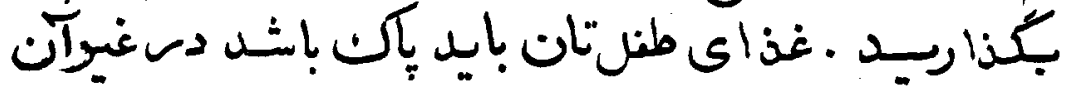

$$
\begin{aligned}
& \text { ب اسهال مبتّلا ميشّود . }
\end{aligned}
$$




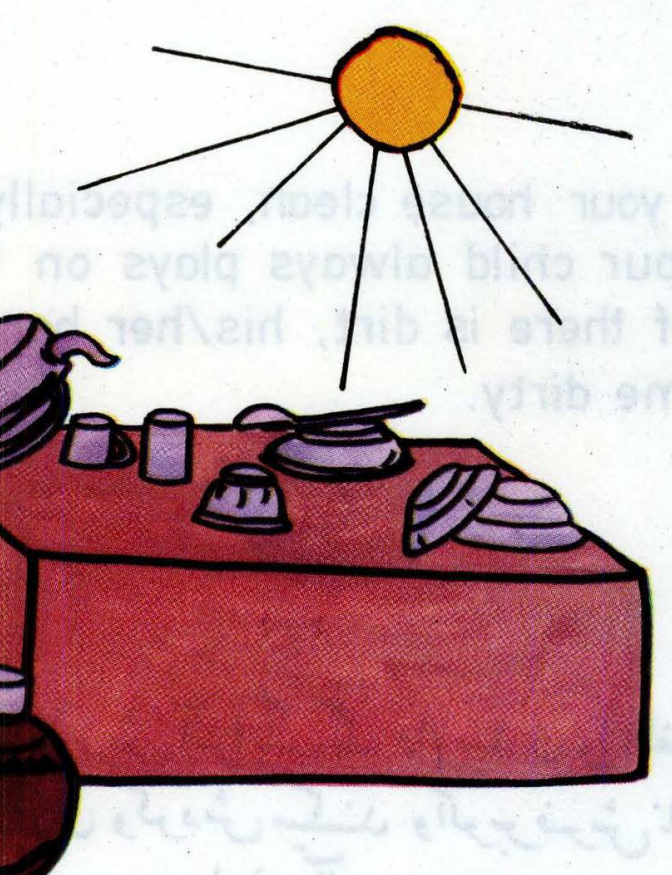




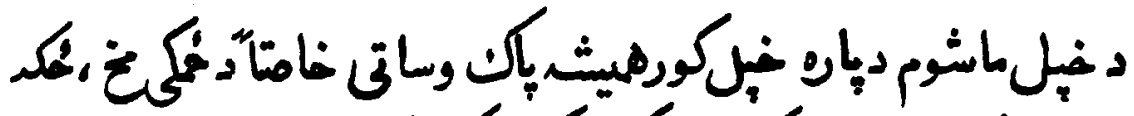

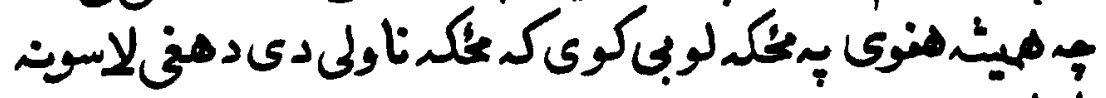

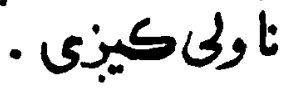

Keep your house clean, especially the floor. for your child always plays on the floor. and if there is dirt, his/her hands will become dirty.

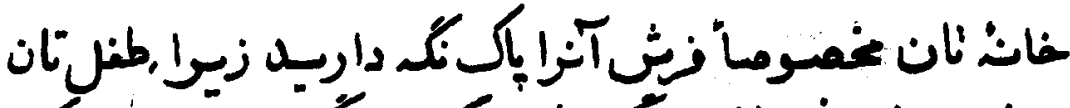

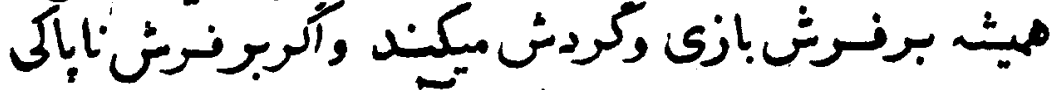

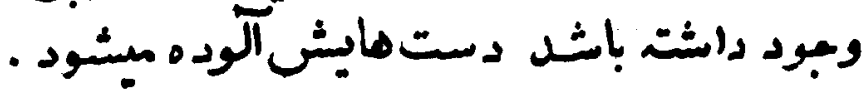




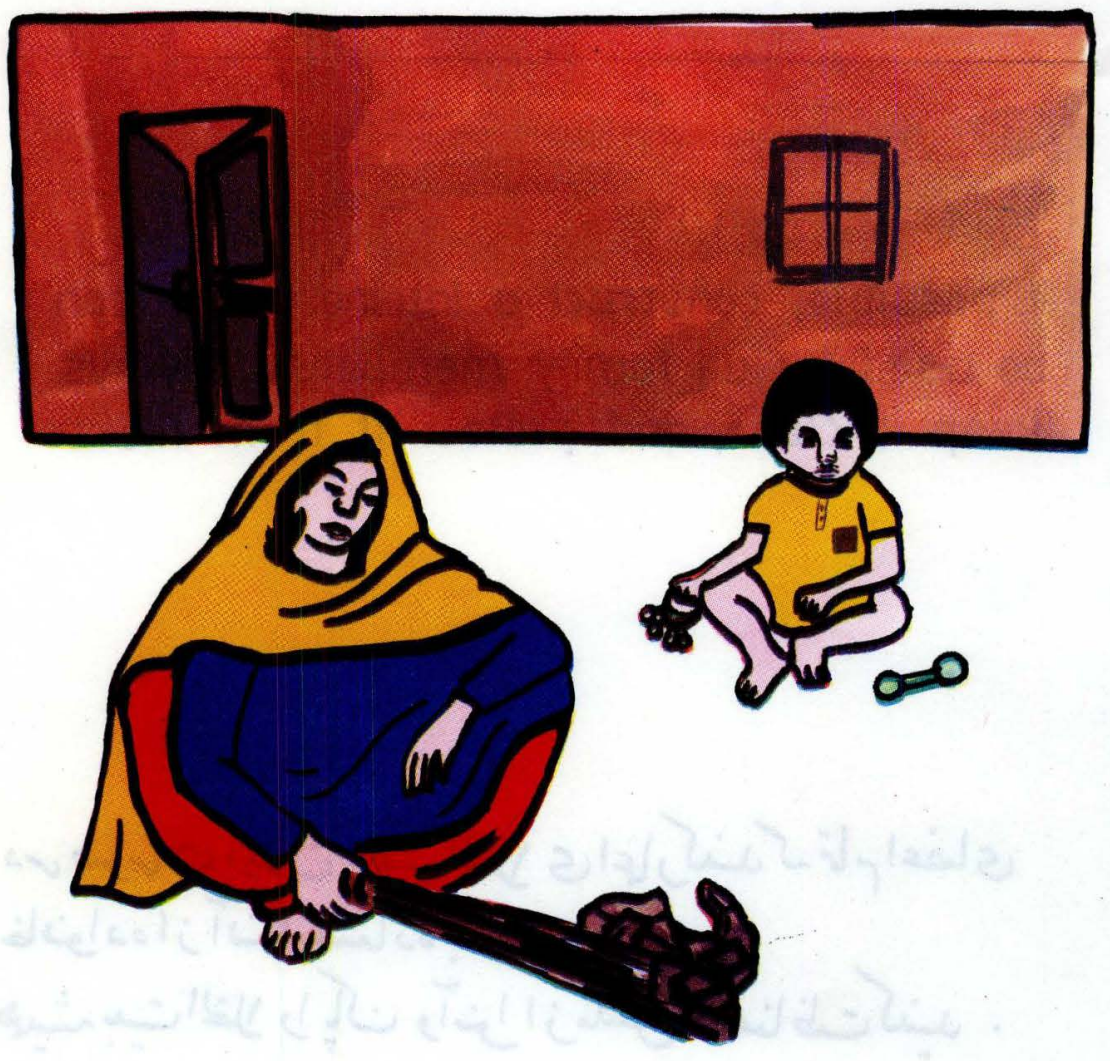




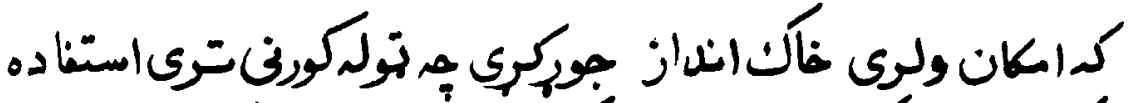

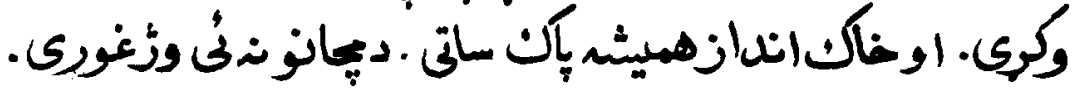

If possible, construct a latrine which can be used by all family members. Always keep it clean, and protect it from flies.

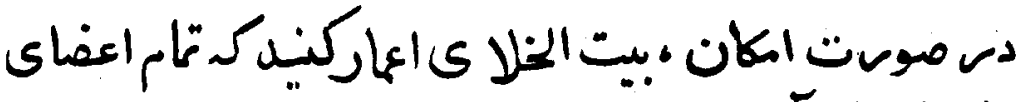

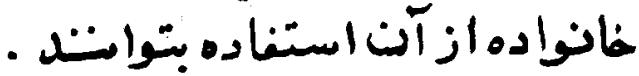

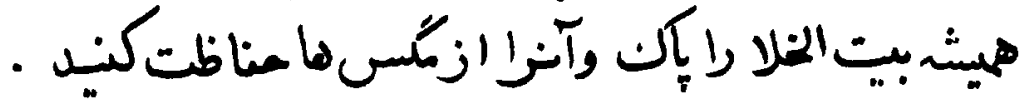




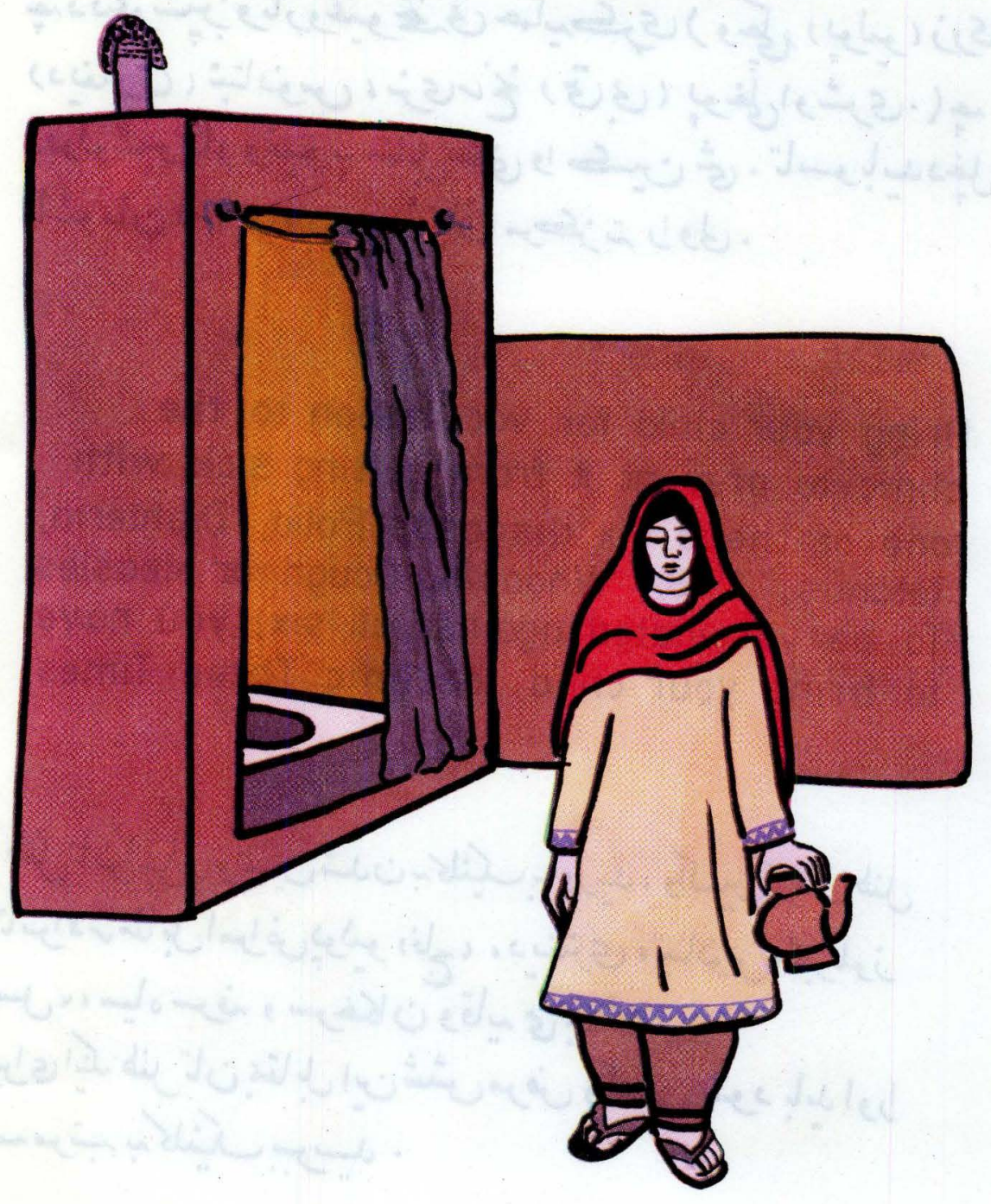




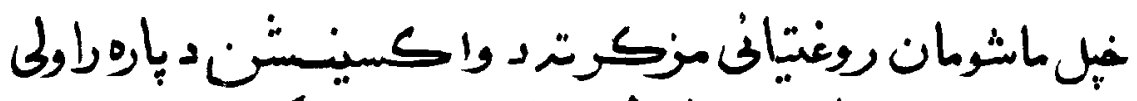

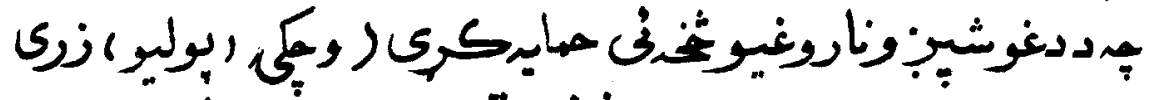

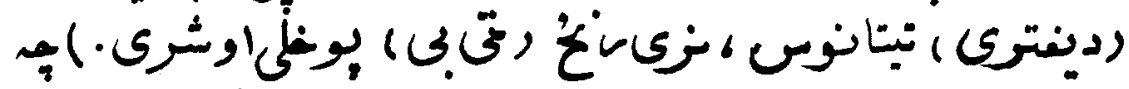

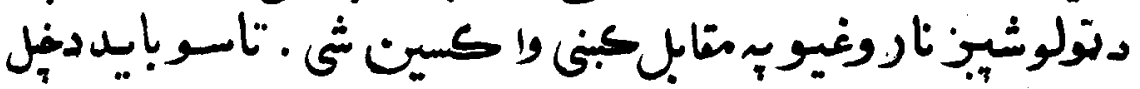

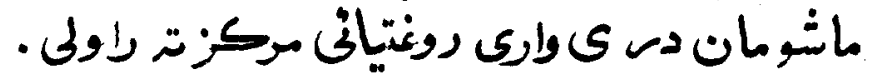

Bring your child for vaccination to the clinic to prevent it from getting sick with one of these six diseases: Polio, Diphteria, Tetanus, T. B., Whooping Cough or Measles, To be vaccinated against all six, you have to bring your child to clinic Three Times

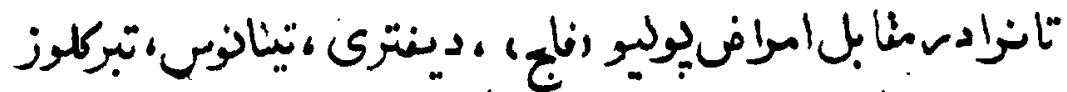

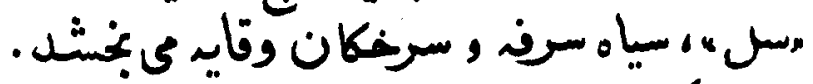

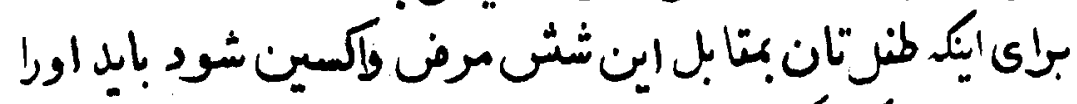

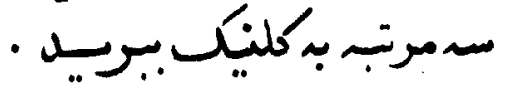




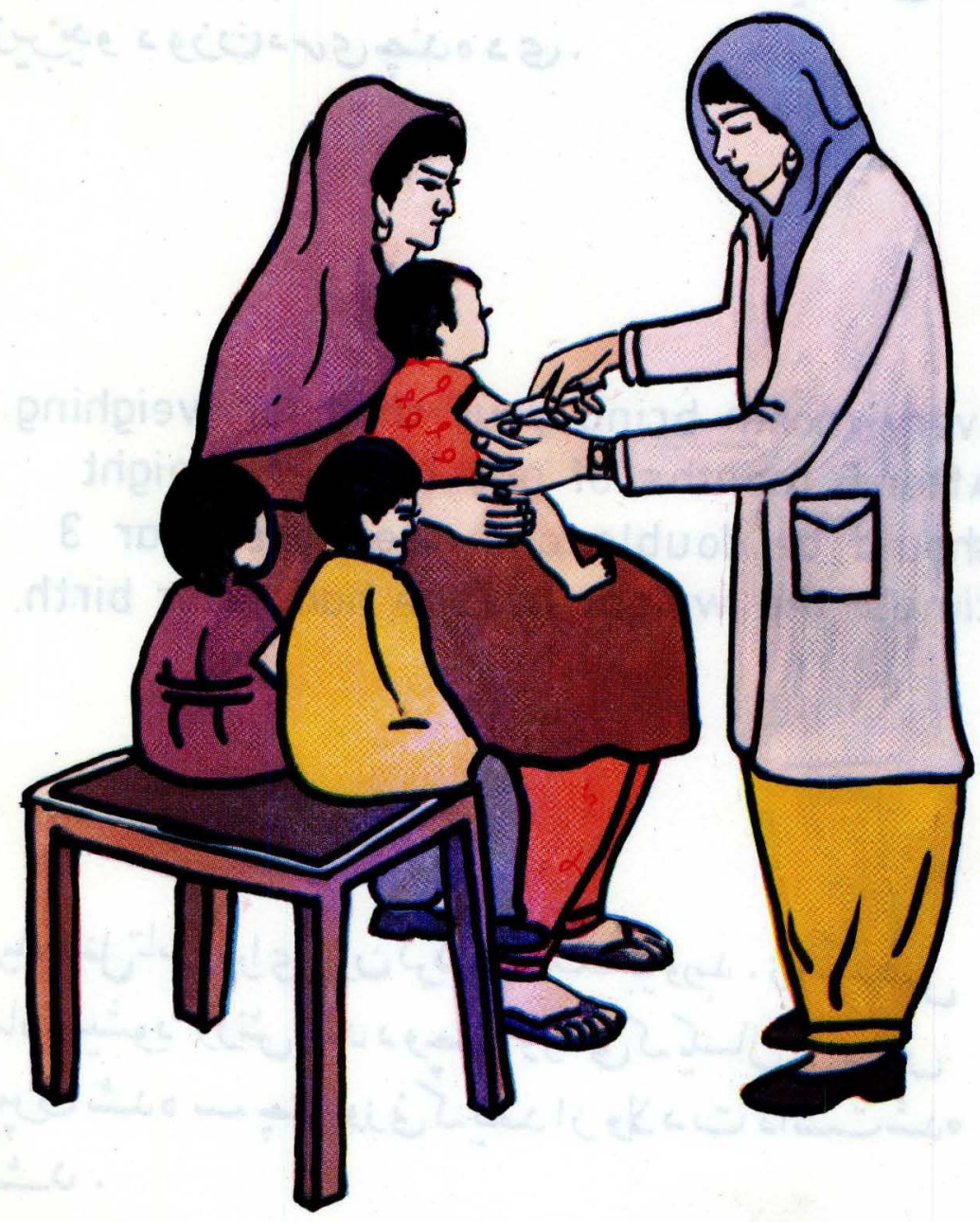




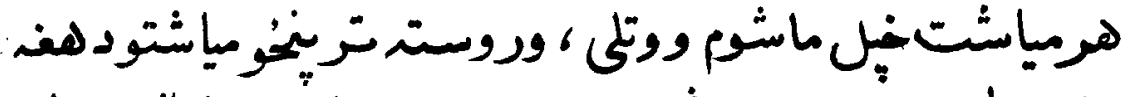

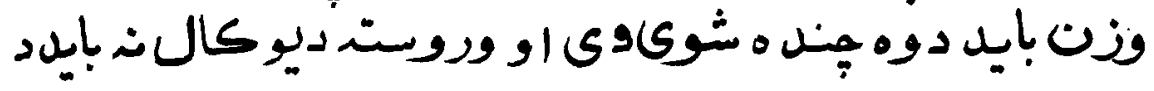

$$
\begin{aligned}
& \text { زيبِيدو دوزندهى جمنده دى . }
\end{aligned}
$$

Every month bring your child for weighing. After 5 months of age his/her weight should be double, and after one year 3 times the weight he/she had after birth.

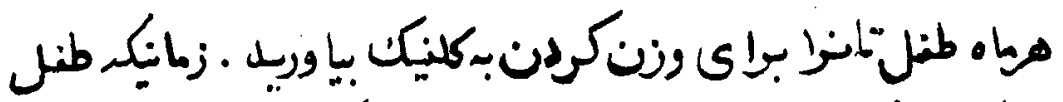

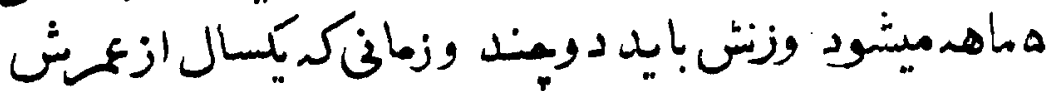

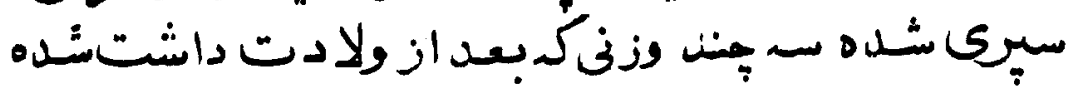

$$
\begin{aligned}
& \text { باثن . }
\end{aligned}
$$




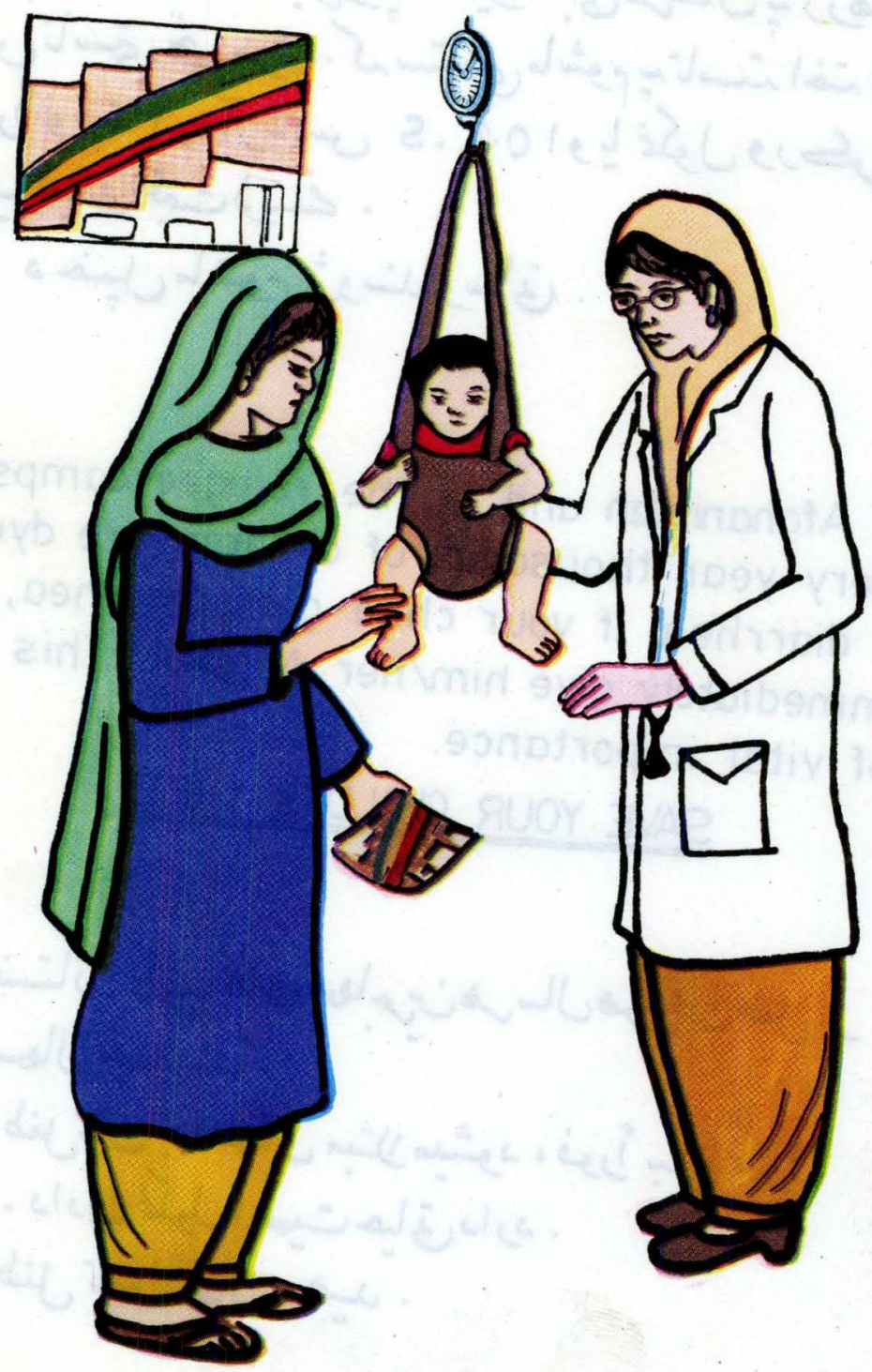


$\dot{\tau}$

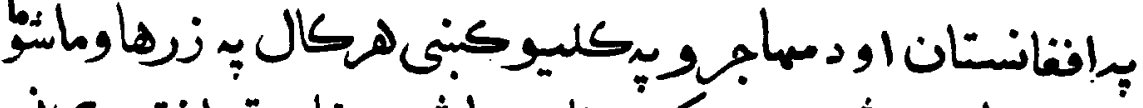

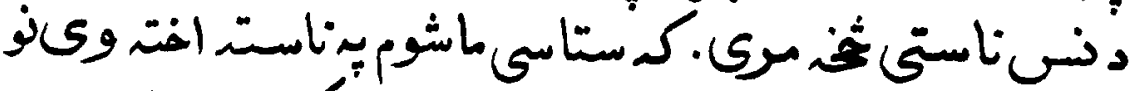

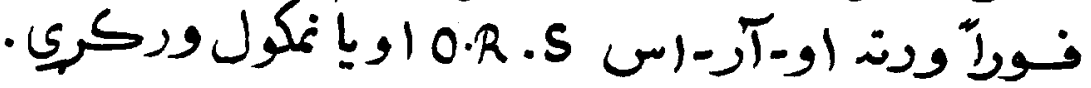

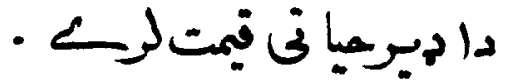

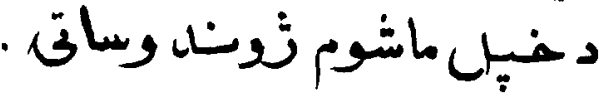

In Afghanistan and in the refugee camps every year thousands of children are dying of diarrhea. If your child gets diarrhea, immediately give him/her Nimkol. This is of vital importance.

\section{SAVE YOUR CHILD'S LIFE.}

درافغانستان وكمبِ هاى مهاعِينهـ سال مزاران طنل از

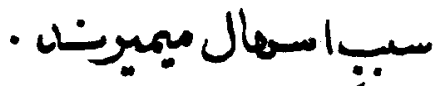

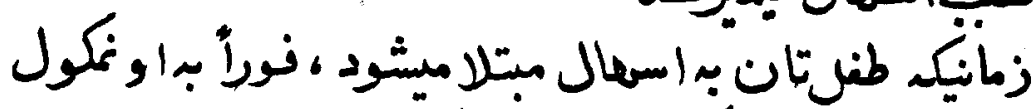

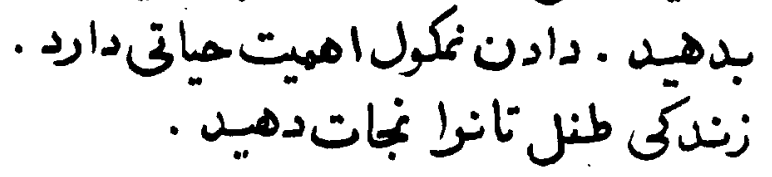

r. 


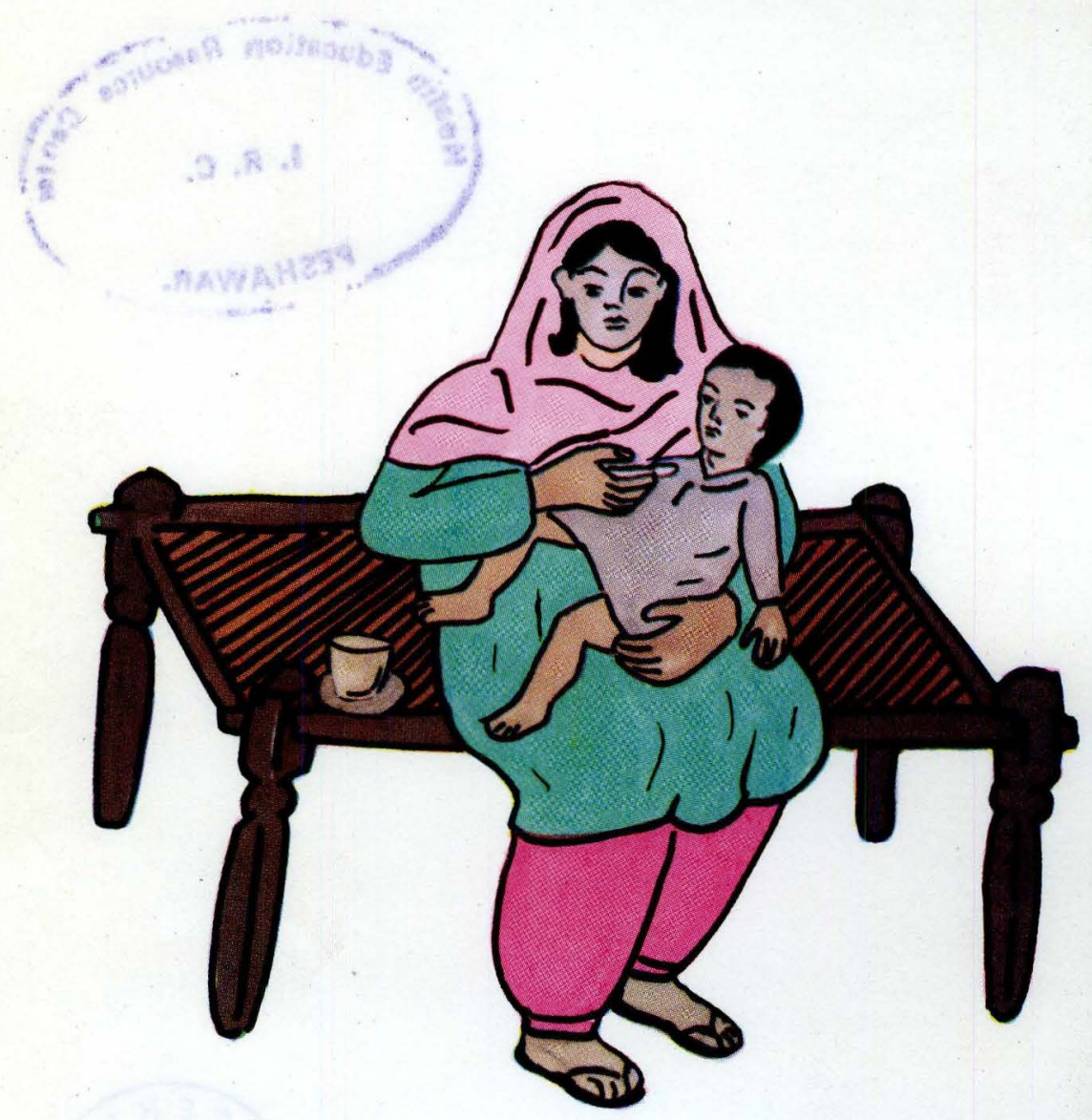

